\title{
Design and Characterization of Superpotent Bivalent Ligands Targeting Oxytocin Receptor Dimers via a Channel-Like Structure
}

\author{
Marta Busnelli, ${ }^{\dagger, \downarrow}$ Gunnar Kleinau, ${ }^{\S}$ Markus Muttenthaler,, Stoytcho Stoev, ${ }^{\perp}$ Maurice Manning, ${ }^{\perp}$
} Lucka Bibic, ${ }^{\#}$ Lesley A. Howell, ${ }^{\#}$ Peter J. McCormick, ${ }^{\#}$ Simona Di Lascio, ${ }^{\neq}$Daniela Braida, Mariaelvina Sala, ${ }^{\dagger,}$ G. Enrico Rovati, ${ }^{\circ}$ Tommaso Bellini, ${ }^{\ddagger}$ and Bice Chini ${ }^{*}{ }^{\dagger}$

${ }^{\dagger}$ CNR, Institute of Neuroscience, Milan, Italy 20129

${ }^{\ddagger}$ Department of Medical Biotechnology and Translational Medicine, Università degli Studi di Milano, Milan, Italy 20129

${ }^{\S}$ Institute of Experimental Pediatric Endocrinology, Charité-Universitätsmedizin Berlin, Berlin, Germany 13353

"Institute for Molecular Bioscience, The University of Queensland, Brisbane, Australia 4072

${ }^{\perp}$ Department of Biochemistry and Cancer Biology, University of Toledo, Toledo, Ohio 43614, United States

${ }^{\#}$ School of Pharmacy, University of East Anglia, Norwich Research Park, Norwich, U.K. NR4 7TJ

ODepartment of Pharmacological and Biomolecular Sciences, Università degli Studi di Milano, Milan, Italy 20133

\section{Supporting Information}
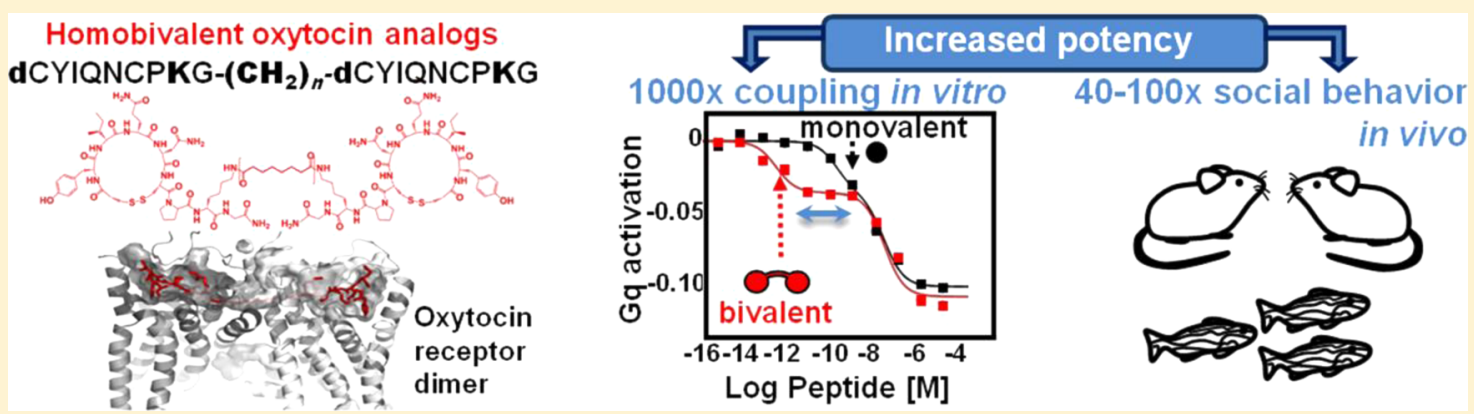

ABSTRACT: Dimeric/oligomeric states of G-protein coupled receptors have been difficult to target. We report here bivalent ligands consisting of two identical oxytocin-mimetics that induce a three order magnitude boost in G-protein signaling of oxytocin receptors (OTRs) in vitro and a 100- and 40-fold gain in potency in vivo in the social behavior of mice and zebrafish. Through receptor mutagenesis and interference experiments with synthetic peptides mimicking transmembrane helices (TMH), we show that such superpotent behavior follows from the binding of the bivalent ligands to dimeric receptors based on a TMH1TMH2 interface. Moreover, in this arrangement, only the analogues with a well-defined spacer length $(\sim 25 \AA)$ precisely fit inside a channel-like passage between the two protomers of the dimer. The newly discovered oxytocin bivalent ligands represent a powerful tool for targeting dimeric OTR in neurodevelopmental and psychiatric disorders and, in general, provide a framework to untangle specific arrangements of G-protein coupled receptor dimers.

\section{INTRODUCTION}

G-protein coupled receptors (GPCRs), the largest eukaryotic family of transmembrane proteins involved in cellular signal transduction, have been shown to associate to form dimers and/or higher order oligomers. ${ }^{1,2}$ Despite their promise as new druggable targets, the molecular details of these complexes have been elusive. Elucidating the number and arrangement of protomers in homo- and hetero-oligomers, the cellular distribution of these different conformations and, most importantly, their functional relevance in normal and pathological conditions, still represents an extraordinary challenge. ${ }^{3}$ Synthetic analogues specifically targeting GPCR homomers and heteromers not only constitute a promising new class of therapeutics but also represent powerful tools to contribute to the enlightenment of how these complexes function.

One strategy to pharmacologically target GPCR dimers is to develop bivalent ligands, single chemical entities composed of two covalently tethered pharmacophores. Such an approach seeks to tether two pharmacophores with a spacer that enables the ligands to bind simultaneously into the two protomers of a dimeric receptor target. ${ }^{4-6}$ There are two general types of bivalent ligands: heterobivalent, where the two pharmacophores are different, and homobivalent, where the two pharmacophores are identical. So far, research has primarily focused on the design of heterobivalent ligands to target

Received: April 13, 2016

Published: July 15, 2016 


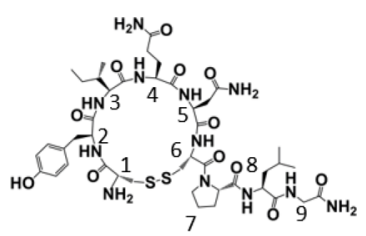

1 OT CYIQNCPLG-NH
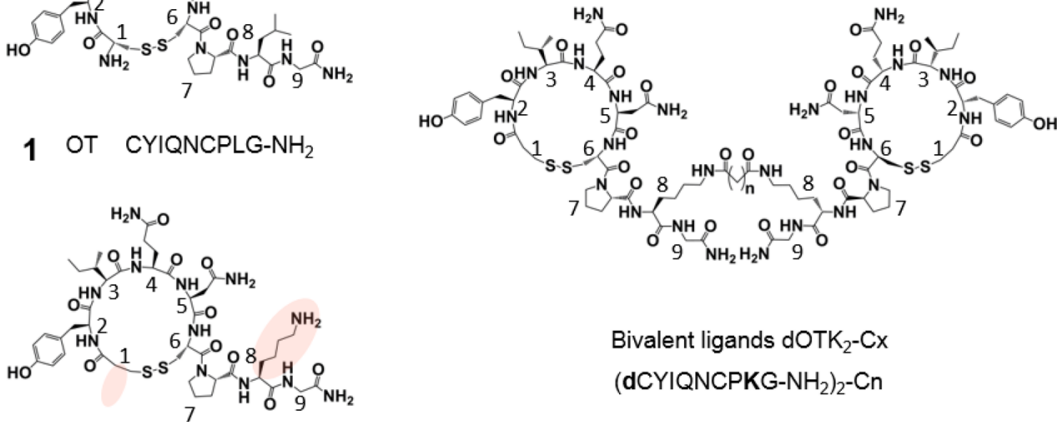

2 dOTK dCYIQNCPKG-NH
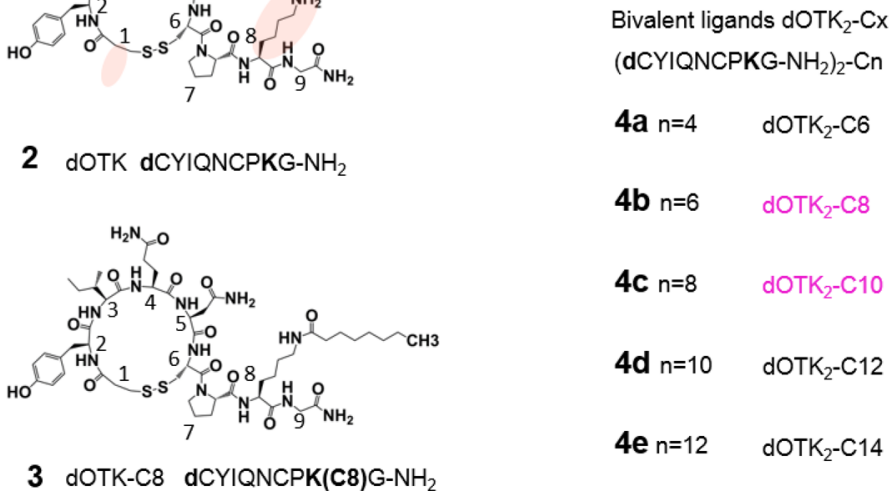

Figure 1. Chemical structure of monovalent and bivalent analogues Schematic representation of OT (1), dOTK (2), dOTK-C8 (3), and bivalent ligands $(\mathbf{4 a}-\mathbf{e})$. OT (1) is a cyclic nonapeptide containing one internal disulfide bond between its Cys $(1)$ and Cys $(6)$ residues, and a tripeptide Pro (7)-Leu (8)-Gly- $\mathrm{NH}_{2}$ (9) tail. The OT-modified peptide dOTK (2) has a deaminated N-terminus, and the Leu residue at position 8 was replaced with a Lys residue (modifications are marked in pink). The dOTK molecule fused to the C8 spacer, dOTK-C8 (3), was used as the control. Two dOTK molecules were covalently tethered with aliphatic spacers of different lengths to generate five homobivalent ligands indicated as dOTK $-\mathrm{Cx}$ $(\mathbf{4 a}-\mathbf{e})$, with $\mathrm{X}$ being the number of carbon atoms between the two lysine groups (including the carbonyl groups of the amide bonds that connect the lysine residues with the spacer). Bivalent ligands with spacers of 8 and 10 atoms (C8 (4b) and C10 (4c)) are marked in magenta.

orthosteric and allosteric binding sites within the same receptor $^{7}$ or in heteromeric receptor complexes. Heterobivalent targeting of heteromeric receptors have been extensively pursued by Portoghese and co-workers ${ }^{8}$ who reported the most successful heterobivalent ligands developed to date and which usually include at least one antagonist molecule. ${ }^{9,10}$ Homobivalent analogues have also been developed and investigated. However, in the majority of cases, homobivalent agonist ligands designed to probe dimeric receptors were found to lose activity and became either partial agonists ${ }^{1-13}$ or, in some cases, antagonists. ${ }^{14,15}$ Scattered reports of homobivalent ligands with increased in vitro and/or in vivo efficacy or potency revealed very short linkers, ${ }^{16}$ more compatible with their binding to different sites within a single protomer ${ }^{7}$ than to the two orthosteric sites of a dimeric receptor. A recent paper reported homobivalent ligands for the melanocortin receptor that display increased binding affinity by 14 - to 25 -fold, slight increased cyclic adenosine $3^{\prime}, 5^{\prime}$-monophosphate (cAMP) signaling potency by 3 - to 5 -fold compared to their monovalent counterparts; in vivo, these ligands significantly decrease feeding but at a dose that was similar to monovalent. ${ }^{17}$

In this work, we pharmacologically targeted dimeric conformations of the human oxytocin receptor (OTR), a prototypic class A GPCR that has been shown to form homoand heterodimers in vitro and in vivo. ${ }^{18}$ OTR homodimers and OTR heterodimers with the highly related vasopressin V1a and V1b receptors have been demonstrated in HEK 293 cells, ${ }^{19}$ and evidence for in vivo OTR heterodimerization with the

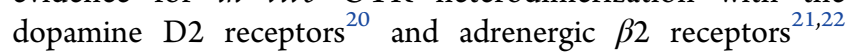
has also been reported.
The oxytocin (OT) system is a key regulator of all the aspects of social behavior, ${ }^{23}$ and in humans, OT facilitates the processing of social information, improves cognitive empathic abilities, and increases interpersonal trust. ${ }^{24}$ On the basis of these premises, OT administration has been proposed and used as a treatment of social deficits in autistic ${ }^{25,26}$ and schizophrenic patients, ${ }^{27}$ representing a domain of great expectations and relevance. ${ }^{28}$ However, the short life of the endogenous peptide and its limited selectivity urges for the development of new potent oxytocin-mimetics for translational studies in vitro and in vivo. ${ }^{29}$ To contribute toward addressing these issues, we synthesized and characterized a series of homobivalent OT analogues designed to specifically activate dimeric forms of the human OTR. We tested these compounds for their capability to bind and activate OTR homodimers and predicted, by molecular modeling, their potential binding modes at a dimeric OTR constellation. The suggested OTR dimer formation was validated by mutagenesis studies and single transmembrane interference assays in combination with G-protein activation. Finally, we used mouse and zebrafish animal models to study highly potent bivalent agonistic OTR ligands in vivo.

\section{RESULTS}

Design Strategy and Synthesis of Homobivalent dOTK Ligands. OT (1) is a nonapeptide neurohormone characterized by a disulfide bond between the two cysteine residues at positions 1 and 6 and a short C-terminal tripeptide (Figure 1). Prior work demonstrated that deamination of cysteine at position 1 and substitution of the leucine residue at position 8 with other amino acids did not affect the 


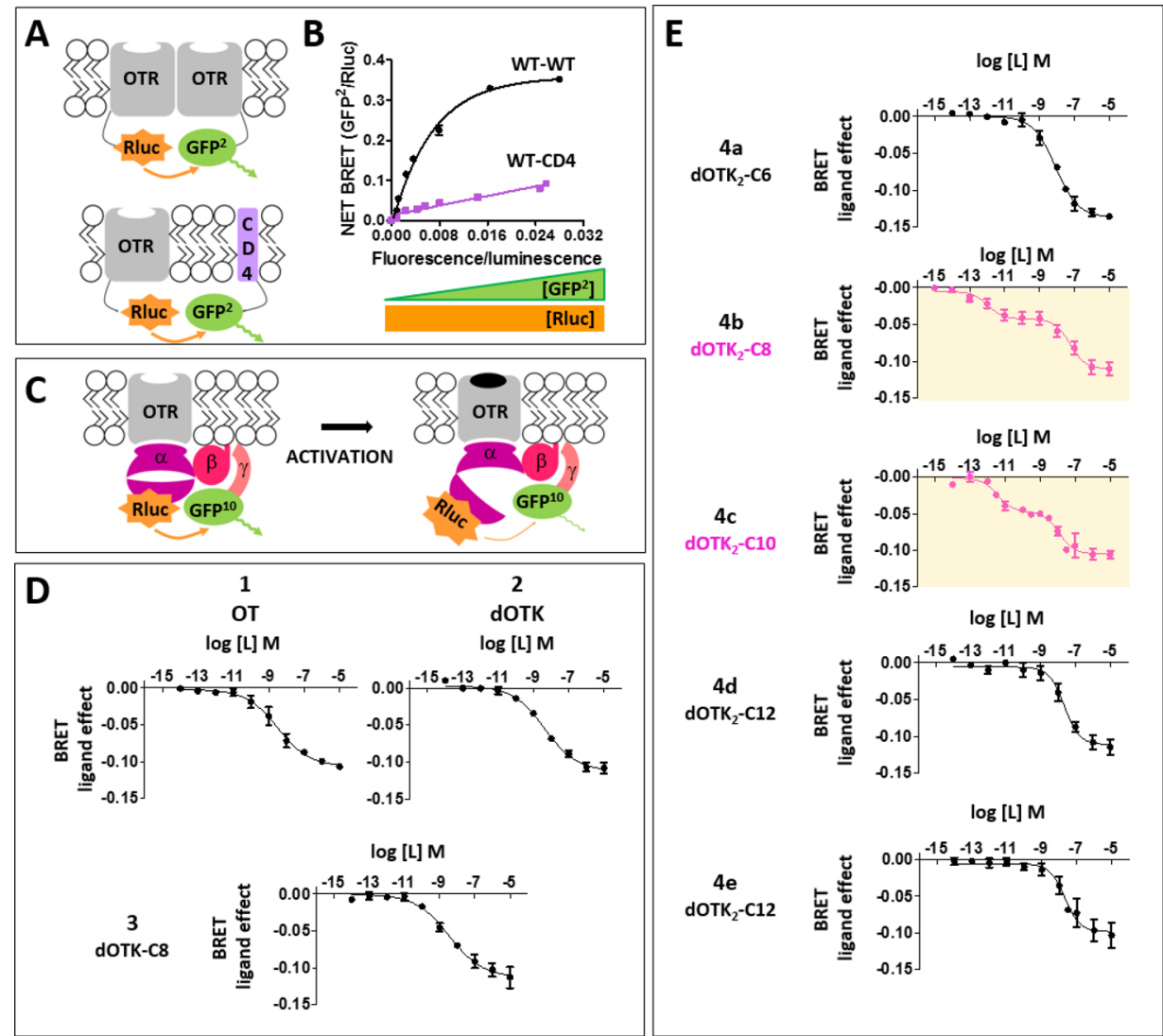

Figure 2. BRET measurement of basal OTR homodimerization and OTR/Gq activation by monovalent and bivalent analogues. (A) Sketch of the receptor constructs used in the BRET saturation assay to study dimerization. OTR fused to the BRET energy donor Renilla Luciferase (OTR-Rluc); OTR fused to the BRET energy acceptor GFP ${ }^{2}$ (OTR-GFP ${ }^{2}$ ) and the CD4 receptor fused to the energy acceptor GFP ${ }^{2}\left(\mathrm{CD}_{4}-\mathrm{GFP}^{2}\right)$. (B) For OTR homodimer formation, cells were transfected with fixed amounts of DNA encoding for OTR-Rluc and increasing amounts of DNA encoding for $\mathrm{OTR}_{\mathrm{GFP}}{ }^{2}$ or, for the negative control, CD4- GFP ${ }^{2}$. Data are expressed as the mean \pm SEM and derived from an individual saturation curve performed in triplicate, representative of at least three independent experiments. (C) Sketch of the Gq BRET activation assay. Energy transfer is measured between Rluc (the energy donor) and $\mathrm{GFP}^{10}$ (the energy acceptor), introduced into the $\alpha$ helical domain of the G $\alpha \mathrm{q}$ subunit and the Nterminal domain of $\mathrm{G} \gamma_{2}\left(\mathrm{GFP}^{10}-\mathrm{G} \gamma_{2}\right)$, respectively. Ligand-induced OTR-Gq activation leads to a conformational rearrangement of the heterotrimeric G protein complex, which promotes GDP release, and that corresponds to a decrease in the BRET energy transfer. BRET was measured in HEK293 living cells coexpressing G $\alpha_{q}$-RLuc8, GFP ${ }^{10}-\mathrm{G} \gamma_{2}, \mathrm{G} \beta_{1}$, and OTR. Cells were left untreated or stimulated with increasing concentrations of (D) the monovalent agonists OT (1), dOTK (2), and dOTK fused to the C8 spacer (dOTK-C8) (3) or (E) the indicated bivalent agonists $(\mathbf{4 a}-\mathbf{e})$. Data were calculated as the difference in the BRET signal measured in the presence and absence of the agonist and are represented as means \pm SEM of at least three independent experiments. The background of graphs reporting biphasic responses is colored in light-orange. Bivalent $\mathrm{dOTK}_{2}-\mathrm{C} 8(\mathbf{4 b})$ and $\mathrm{dOTK}_{2}-\mathrm{C} 10(4 \mathbf{c})$ activation curves are in magenta.

pharmacological properties of the peptide toward the OTR. ${ }^{30}$ In particular, OT deaminated at position 1 and bearing a lysine at position 8 and indicated here as $\operatorname{dOTK}(2)$ (Figure 1) could be conjugated to the bulky group DOTA $(1,4,7,10$ tetraazacyclododecane-1,4,7,10-tetraacetic acid) without showing any significant drop in the affinity for the OTR ${ }^{30}$ On the basis of these observations, we used the lysine side chain at position 8 of dOTK as the conjugation site to generate a series of differently sized bivalent dOTK ligands $(4 \mathbf{a}-\mathbf{e})$, joined by alkane spacers of different lengths, from C6 to C14 atoms (Figure 1). Alkane spacers were chosen on the basis of their previous successful use in bivalent ligand design; ${ }^{8}$ moreover, alkane spacers are flexible and dynamic, their reaction conditions fairly well established and with high yields, and are commercially available in a whole range of lengths. The chemical structure and nomenclature of these compounds are schematically reported in Figure 1 and their synthesis in Supporting Information, Experimental Section.

Mono- and Biphasic Activation of OTR by Monovalent and Bivalent dOTK Ligands. The capability of OTR to form homodimers was confirmed via a bioluminescence resonance energy transfer $(\mathrm{BRET})^{31}$ saturation assay (Figure $\left.2 \mathrm{~A}\right)$. In this experiment, HEK293 cells are cotransfected with a fixed DNA amount of OTR fused to the Renilla reniformis Luciferase (Rluc, the BRET energy donor) and increasing DNA amounts of OTR fused to the blue-shifted variant of Aequorea Victoria green fluorescent protein $\mathrm{GFP}^{2}$ (the BRET energy acceptor); this allows for the formation of OTR-Rluc/OTR-GFP ${ }^{2}$ dimeric complexes in a dose-dependent manner, which, by consequence, leads to a dose-dependent increase in the BRET signal, up to a point (a saturation plateau) where all OTR-Rluc receptors are complexes with OTR-GFP ${ }^{2}$ receptors. As a control to rule out the possibility that the observed BRETsignal is not a consequence of stochastic collision events due to receptor overexpression, the distantly related CD4 receptor fused to $\mathrm{GFP}^{2}$ (CD4-GFP ${ }^{2}$ ) was coexpressed with OTR-Rluc. As shown in Figure 2B, the OTR-Rluc and CD4-GFP ${ }^{2}$ pair failed to produce a hyperbolic curve, whereas a robust and saturable BRET signal $\left(\right.$ BRET $\left._{\max } 0.38 \pm 0.04\right)$ was obtained for 
Table 1. Pharmacological Parameters of Monovalent and Bivalent Ligands at the WT OTR ${ }^{a}$

\begin{tabular}{|c|c|c|c|c|}
\hline & $\mathrm{EC}_{50}($ mean $\pm \mathrm{SE})$ & Hill coefficient (mean $\pm S E$ ) & $E_{\max }($ mean $\pm \mathrm{SE})$ & $n$ \\
\hline OT (1) & $2.1 \pm 1.3 \mathrm{nM}$ & $-0.49 \pm 0.10$ & $-0.11 \pm 0.006$ & 3 \\
\hline dOTK (2) & $4.0 \pm 1.6 \mathrm{nM}$ & $-0.51 \pm 0.07$ & $-0.11 \pm 0.005$ & 5 \\
\hline $\operatorname{dOTK}(2)(*)$ & $\begin{array}{l}\mathrm{EC}_{50 \mathrm{Hi}} 265 \pm 89 \mathrm{pM} \\
\mathrm{EC}_{50 \mathrm{Lo}} 74.8 \pm 67 \mathrm{nM}\end{array}$ & $\begin{array}{l}\text { fixed }-1 \\
\text { fixed }-1\end{array}$ & $-0.10 \pm 0.003$ & 5 \\
\hline dOTK-C8 (3) & $4.1 \pm 4.6 \mathrm{nM}$ & $-0.50 \pm 0.09$ & $-0.11 \pm 0.008$ & 3 \\
\hline $\mathrm{dOTK}_{2}-\mathrm{C} 6(\mathbf{4 a})$ & $11.78 \pm 1.7 \mathrm{nM}$ & $-0.67 \pm 0.09$ & $-0.13 \pm 0.005$ & 3 \\
\hline $\mathrm{dOTK}_{2}-\mathrm{C} 8(\mathbf{4 b})$ & $\begin{array}{l}\mathrm{EC}_{50 \mathrm{Hi}} 0.8 \pm 0.7 \mathrm{pM} \\
\mathrm{EC}_{50 \mathrm{Lo}} 67.3 \pm 17.9 \mathrm{nM}\end{array}$ & $\begin{array}{l}\text { fixed }-1 \\
\text { fixed }-1\end{array}$ & $-0.11 \pm 0.004$ & 5 \\
\hline $\mathrm{dOTK}_{2}-\mathrm{C} 10(4 \mathrm{c})$ & $\begin{array}{l}\mathrm{EC}_{50 \mathrm{Hi}} 2.8 \pm 1.9 \mathrm{pM} \\
\mathrm{EC}_{50 \mathrm{Lo}} 13 \pm 5.5 \mathrm{nM}\end{array}$ & $\begin{array}{l}\text { fixed }-1 \\
\text { fixed }-1\end{array}$ & $-0.10 \pm 0.004$ & 3 \\
\hline $\mathrm{dOTK}_{2}-\mathrm{C} 12(4 \mathrm{~d})$ & $20.1 \pm 11.5 \mathrm{nM}$ & $-0.74 \pm 0.19$ & $-0.11 \pm 0.007$ & 3 \\
\hline $\mathrm{dOTK}_{2}-\mathrm{C} 14(4 \mathrm{e})$ & $29.4 \pm 11.6 \mathrm{nM}$ & $-0.68 \pm 0.24$ & $-0.10 \pm 0.010$ & 4 \\
\hline
\end{tabular}

${ }^{a}$ Parameters obtained in BRET experiments (Figure 2) describe the activity of monovalent and bivalent agonists on Gq signaling in wild type (WT) OTR. Data were analyzed by a four-parameters logistic model for monotonic curves or by a seven-parameter model for biphasic curves. For biphasic fitting, in which the Hill coefficient was fixed equal to -1 for both phases, $\mathrm{EC}_{50 \mathrm{Hi}}$ refers to the "high" potency site and $\mathrm{EC}_{50 \mathrm{Lo}}$ to the "low" potency site. Estimated parameter values represent means \pm SE of three-five independent experiments performed at least in triplicate. (*) Biphasic fitting of dOTK (2) data.

OTR, a result consistent with the formation of OTR-Rluc/ OTR-GFP ${ }^{2}$ dimers.

To functionally evaluate monovalent and bivalent ligands, we employed a BRET-based biosensor that measures the ligand induced $\mathrm{G}$ protein activation (Figure $2 \mathrm{C}$ ). In this biosensor, the BRET energy donor Rluc is inserted within the $\mathrm{G} \alpha$ subunit amino acid sequence, and the acceptor, a variant of the green fluorescent protein $\left(\mathrm{GFP}^{10}\right)$, is N-terminally fused to the $\mathrm{G} \gamma_{2}$ subunit $\left(\mathrm{GFP}^{10}-\mathrm{G} \gamma_{2}\right){ }^{31-33}$ Ligand-induced OTR-Gq activation leads to GDP release coupled to a conformational rearrangement of the heterotrimeric $G$ protein complex and, by consequence, to a decrease in the BRET ratio. Using this assay, we previously demonstrated that OT (1) promotes OTR coupling to several G-protein isoforms in a concentrationdependent manner, allowing the identification of $\mathrm{Gq}$ as being engaged at a lower peptide concentration. ${ }^{34}$ Several OT analogues were analyzed for functional selectivity and biased properties; among these analogues, dOTK (2) was able to activate the Gq pathway with a maximal effect similar to that of OT (1). ${ }^{34}$ Here, OT (1) and dOTK (2) full concentrationresponse curves for OTR/Gq activation were generated (Figure 2D). Data were best fitted by a four-parameter logistic model for monotonic curves, with a resulting $\mathrm{EC}_{50}$ of $4.0 \pm 1.6 \mathrm{nM}$ (SE) for dOTK (2), a value that is comparable with that obtained for OT (1), $\mathrm{EC}_{50}=2.1 \pm 1.3 \mathrm{nM}$ (SE) (Table 1). dOTK (2) and OT (1) thus present identical pharmacological properties toward OTR/Gq activation, validating the choice of the dOTK (2) analogue as a parent structure for the bivalent synthesis. Interestingly, OT (1) and dOTK (2) curves revealed comparable Hill coefficients $(-0.49$ for OT $(1)$ and -0.51 for dOTK $(2))$ statistically different from $-1(P<0.05)$ (Table 1$)$, suggesting the activation of a nonhomogeneous population of OTRs.

The bivalent ligand series was then evaluated with the Gq BRET biosensor. As shown in Figure 2E, the concentrationresponse curves of $\mathrm{dOTK}_{2}-\mathrm{C} 6(\mathbf{4 a}), \mathrm{dOTK}_{2}-\mathrm{C} 12(4 \mathrm{~d})$, and $\mathrm{dOTK}_{2}-\mathrm{C} 14(4 \mathrm{e})$ were again monotonic and could be best fitted with a classical logistic model, with a Hill coefficient different from $-1(P<0.05)$ (Table 1$)$. On the contrary, the two bivalent ligands, $\mathrm{dOTK}_{2}-\mathrm{C} 8(4 \mathrm{~b})$ and $\mathrm{dOTK}_{2}-\mathrm{C} 10(4 \mathrm{c})$, promoted $\mathrm{Gq}$ activation with a biphasic behavior that could be best fitted by a model for biphasic dose-response curves assuming a Hill coefficient equal to -1 for both phases. The resulting $\mathrm{EC}_{50}$ for $\mathrm{dOTK}_{2}-\mathrm{C} 8(\mathbf{4 b})$ and $\mathrm{dOTK}_{2}-\mathrm{C} 10$ (4c) (Table 1) indicated a first activation process with an $\mathrm{EC}_{50 \mathrm{Hi}}$ in the pico-molar range $\left(\mathrm{EC}_{50 \mathrm{Hi}}=0.8 \pm 0.7 \mathrm{pM}(\mathrm{SE})\right.$ for $\mathrm{dOTK}_{2}-\mathrm{C} 8(4 \mathbf{b})$ and $\mathrm{EC}_{50 \mathrm{Hi}}=2.8 \pm 1.9 \mathrm{pM}$ (SE) for $\left.\mathrm{dOTK}_{2}-\mathrm{C} 10(4 \mathrm{c})\right)$ and a second activation process with an $\mathrm{EC}_{50 \mathrm{Lo}}$ in the high nanomolar range $\left(\mathrm{EC}_{50 \mathrm{Lo}}=67.3 \pm 17.9 \mathrm{nM}\right.$ (SE) for $\mathrm{dOTK}_{2}-\mathrm{C} 8(4 \mathbf{b})$ and $\mathrm{EC}_{50 \mathrm{Lo}}=13 \pm 5.5 \mathrm{nM}(\mathrm{SE})$ for $\left.\mathrm{dOTK}_{2}-\mathrm{C} 10(\mathbf{4 c})\right)$.

Statistical analysis of the maximal activation values $\left(E_{\max }\right)$ (Table 1), indicated that the $E_{\max }$ values of the bivalent analogues were not statistically different from that of dOTK (2), suggesting that dOTK (2) and the bivalent compounds $(4 a-e)$ activated the same pool of receptors.

Finally, we assayed the contribution of the spacer by synthesizing the monovalent dOTK-C8 (3) analogue. As shown in Figure 2D, dOTK-C8 (3) generated a monophasic activation curve with a calculated $\mathrm{EC}_{50}$ of $4.1 \pm 4.6 \mathrm{nM}(\mathrm{SE})$ and a Hill coefficient $=-0.50$ statistically different from $-1(P$ $<0.05)$, comparable to those of dOTK (3) $(4.0 \pm 1.6 \mathrm{nM}(\mathrm{SE})$, Hill coefficient $=-0.51$, and OT $(1)(2.1 \pm 1.3 \mathrm{nM}(\mathrm{SE})$, Hill coefficient $=-0.49)$. We can therefore exclude a significant contribution to the biphasic activation process of the spacer alone.

The binding features of dOTK (2) and $\mathrm{dOTK}_{2}-\mathrm{C} 8(\mathbf{4 b})$ to the OTR were then investigated in competition binding experiments (Figure 3). dOTK $2-\mathrm{C} 8$ (4b) data were best fitted with a biphasic curve characterized by a high affinity $\left(K_{\mathrm{iHi}}=\right.$ $0.08 \pm 0.05 \mathrm{pM}(\mathrm{SE}))$ and low affinity component $\left(K_{\mathrm{iLo}}=1.24\right.$ $\pm 0.6 \mathrm{nM}(\mathrm{SE}))$, in agreement with BRET curves. dOTK (2) could be fitted by a two-site binding model $(P<0.01)$ with $K_{\mathrm{iHi}}$ of $21 \pm 6.93 \mathrm{pM}(\mathrm{SE})$ and a $K_{\mathrm{iLo}}$ of $3.35 \pm 2.07 \mathrm{nM}(\mathrm{SE})$ (Figure 3 ). $K_{\mathrm{iHi}}$ and $K_{\mathrm{iLo}}$ values obtained in binding assays resulted in being left-shifted by a factor of 10 with respect to $\mathrm{EC}_{50 \mathrm{Hi}}$ and $\mathrm{EC}_{50 \mathrm{Lo}}$ values obtained in activation experiments, a phenomenon that can result from the different nature of the assays performed (binding is performed in competitive conditions using as a radioligand a monovalent antagonist, while activation is a noncompetitive assay) and/or by the experimental conditions in which the two assays were performed (temperature, buffers, and incubation times). 


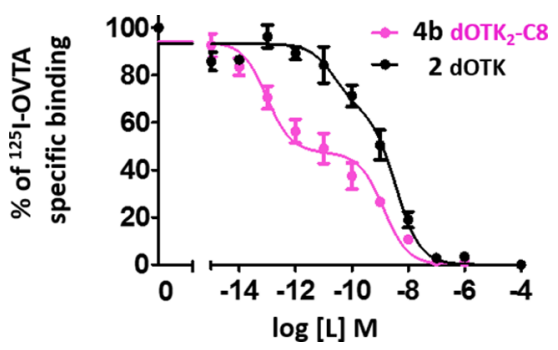

Figure 3. Binding properties of $\mathrm{dOTK}$ and $\mathrm{dOTK}_{2}$-C8. Binding properties of dOTK (1) and $\mathrm{dOTK}_{2}-\mathrm{C} 8(\mathbf{4 b})$ were determined by competition experiments on membranes of COS7 cells transfected with the OTR. Membranes were incubated with $10 \mathrm{pM}\left[{ }^{125} \mathrm{I}\right]-\mathrm{OVTA}$ in the presence of increasing concentrations of dOTK (1) (in black) or $\mathrm{dOTK}_{2}-\mathrm{C} 8$ (4b) (in magenta); nonspecific binding was determined in the presence of OT $(1 \mu \mathrm{M})$. Data points are represented as the mean \pm SEM of three (dOTK) and six $\left(\mathrm{dOTK}_{2}-\mathrm{C} 8\right)$ independent experiments each performed in triplicate. [L] ligand concentration.

Binding and activation data suggest the coexistence of different receptor subpopulations, a concept observed before in single molecule studies looking at other receptors. ${ }^{35,36}$ Although alternative explanations could in principle arise from cooperativity, no available model based on such a mechanism is able to account at the same time for biphasic binding and activation. Moreover, only negative cooperativity has been reported for the OTR ${ }^{37}$ Since the most plausible explanation of our observations is thus the presence of different receptor subpopulations, we analyzed the pharmacological features of the activation curves by dissecting their possible components (Figure 4).

dOTK (2) activation, although best fitted by a monotonic curve, is characterized by a Hill coefficient $=-0.51$ in the BRET assay. As shown in Figure 4B (dashed black lines, whose sum is the continuous black line), this same activation curve can be broken up as a sum of two independent decays with Hill coefficient $=-1$, resulting in two $\mathrm{EC}_{50}\left(\mathrm{EC}_{50 \mathrm{Hi}}\right.$ and $\left.\mathrm{EC}_{50 \mathrm{Lo}}\right)$ differing by up to 2 orders of magnitude. Direct comparison of the $\mathrm{EC}_{50 \mathrm{Hi}}$ and $\mathrm{EC}_{50 \mathrm{Lo}}$ between $\mathrm{dOTK}(2)$ and $\mathrm{dOTK}_{2}-\mathrm{C} 8$ (4b) shows that while the $\mathrm{EC}_{50 \mathrm{Lo}}$ values (dOTK (2), $74.8 \mathrm{nM}$; dOTK $_{2}-\mathrm{C} 8(4 \mathrm{~b}), 67.3 \mathrm{nM}$ ) are statistically not different, the $\mathrm{EC}_{50 \mathrm{Hi}}$ values (dOTK (2), $265 \mathrm{pM}$; dOTK $2-\mathrm{C} 8$ (4b), $0.8 \mathrm{pM}$ ) are significantly different (Table 1$)$. Consistently, our binding studies show low affinity sites with identical $K_{\mathrm{i}}$ values for dOTK (2) $(1.24 \mathrm{nM})$ and $\mathrm{dOTK}_{2}-\mathrm{C} 8(4 \mathrm{~b})(3.35 \mathrm{nM})$ and a high affinity site with 2 orders of magnitude different $K_{\mathrm{i}}$ values for $\operatorname{dOTK}(2)(21 \mathrm{pM})$ and $\mathrm{dOTK}_{2}-\mathrm{C} 8$ (4b) (0.08 pM). These data indicate that the OTR exists in (i) a high affinity state whose affinity is markedly boosted only by bivalent ligands and (ii) a low affinity state that does not discriminate between monovalent and bivalent analogues. On the basis of this evidence, we hypothesize that the first component of the bivalent activation curve is sustained by high affinity sites,

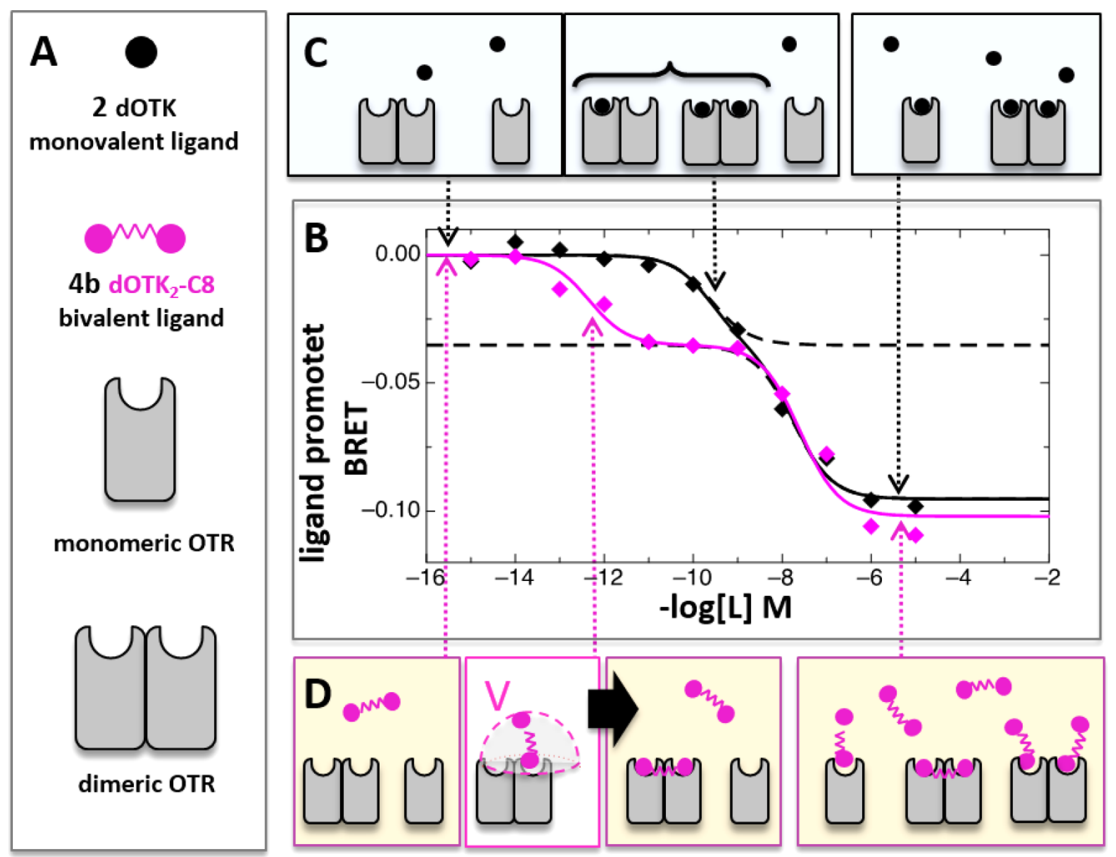

Figure 4. Analysis of the BRET OTR/Gq activation curves. (A) Sketches of the molecules used in this study: monovalent dOTK (1) and bivalent $\mathrm{dOTK}_{2}-\mathrm{C} 8$ (4b) ligands, and monomeric and dimeric OTR. (B) OTR activation curves as measured by the BRET biosensor vs the log of the concentration of monovalent (black dots) and of bivalent ligands (magenta dots). Continuous lines represent the best fittings obtained by the sum of two linear processes. Dashed black lines represent separately the two single linear processes added to obtain the best fit. [L] is the ligand concentration. (C) Cartoon description of the dose-dependent steps of dimeric and monomeric OTR activation by the monovalent ligand; left panel, dOTK (2) concentrations at which no detectable activation is observed; middle panel, intermediate dOTK (2) concentrations at which activation is compatible with binding to one or to both sites of dimeric OTR, two possibilities that cannot be discerned in this study (Supporting Note 1); and right panel, activation of monomeric OTR at high dOTK (2) concentration. (D) Cartoon description of the dose-dependent stages of dimeric and monomeric OTR activation by the bivalent ligand. Left panel: $\mathrm{dOTK}_{2}-\mathrm{C} 8(\mathbf{4 b})$ concentrations at which no detectable activation is observed; intermediate panel, activation of the dimeric OTR at low $\mathrm{dOTK}_{2}-\mathrm{C} 8(\mathbf{4 b})$ concentrations, compatible with a process in which the binding of the first pharmacophore constrains the second one within a volume $(V)$, allowing the docking of the bivalent ligand into the two binding sites of a dimeric OTR; and right panel, activation of monomeric OTR at higher $\mathrm{dOTK}_{2}-\mathrm{C} 8(\mathbf{4 b})$ concentrations. 
corresponding to dimeric receptors, that are activated in a dosedependent way at concentrations between $10^{-13}$ and $10^{-11} \mathrm{M}$; the maximal activation of these sites is achieved at $10^{-11} \mathrm{M}$, and from $10^{-11}$ to $10^{-9} \mathrm{M}$, the curve stays flat, as expected for a saturating phenomenon. At $10^{-9} \mathrm{M}$, a population of low affinity sites, corresponding to monomeric receptors, starts to be activated, leading to the second component of the biphasic curve; these sites are activated in a dose-dependent way at concentrations between $10^{-9}$ and $10^{-7} \mathrm{M}$.

Because these data strongly suggest that the high affinity sites correspond to dimeric receptors, while the low affinity sites correspond to monomeric receptors, we engaged in receptor modeling and docking analysis to identify the monomeric and dimeric receptor conformations sustaining monovalent and bivalent binding and activation.

Molecular Modeling and Docking of Monovalent and Bivalent dOTK Ligands into Monomeric and Dimeric OTR. The molecular models for monomeric OTR complexed with dOTK (2) (Figure S1) and protomers of dimeric OTRs complexed with bivalent $\mathrm{dOTK}_{2}-\mathrm{C} 8$ were developed (Figure 5) (for details, see Supporting Information).

Our docking studies suggest that the monomeric OTR binds OT (1) and dOTK (2) in a region between the extracellular loops (ECLs) and extracellular ends of the transmembrane helices (TMHs). ${ }^{30,38}$ The model (Supporting Information) implicates the following ligand/receptor amino acid pairs involved in the binding of dOTK to the OTR (in the binding pocket): Tyr2/Tyr200-Phe291; Ile3/Met123-Leu201-Ile201; Gln4/Ser298; Asn5/Gln119-Gln295; and Lys8/(Glu42)Asp100. This docking also supports an orientation of the ligand's C-terminal tail toward the ECL1/extracellular part of $\mathrm{TMH} 1$ and the cyclic dOTK ring in the transmembrane region close to the ECL2 (see Figure S1 for details and Supporting Information, Experimental Section for the list of amino acids constituting the ligand-binding pocket).

Stimulated by experimental evidence that suggests different protomer-protomer interfaces in different GPCR dimers, ${ }^{39-43}$ we designed two models of OTRs protomer-protomer interfaces, either constituted by amino acid side chains between TMH1-TMH2-helix8 (Figure 5A) or between TMH5-TMH6 (Figure 5B). Remarkably, only the OTR dimers with a protomer interface at TMH1-TMH2-helix8 allow for the computational binding of both moieties of our homobivalent C8 (4b) and C10 (4c) ligands into the two orthosteric binding sites (Figure $5 \mathrm{~A}$ and $\mathrm{B}$ ). Of note, the docking of dOTK-C8 (4b) inside dimers with a TMH1-TMH2-helix8 protomerprotomer interface is possible thanks to the presence of a channel-like passage between the two interacting helices (TMH1-TMH2) (Figure 5C). This channel-like passage allows the docking of the $\mathrm{C} 8$ (Figure 5A) and C10 spacers maintaining the pharmacophore binding mode of the monomeric OTR/dOTK complex. In this model, the channel opening toward the membrane is mainly constituted at the protomer surface by Ala39, Val43, Leu97, and Leu98 and is accompanied by further residues of ECL1, such as Ile101. Indeed, the presence of a shortcut channel is crucial to combine the limited length of C8 and C10 spacers with the intrinsic size of the OTR and an optimal docking of $\operatorname{dOTK}(2)$ into the orthosteric binding sites. This fact can be immediately recognized by analyzing Figure $5 \mathrm{D}$, which shows that the conformation adopted by the spacers to connect the two dOTK pharmacophores is almost linear. No alternative arrangements of $\mathrm{dOTK}_{2}-\mathrm{C} 8(\mathbf{4 b})$ and $\mathrm{dOTK}_{2}-\mathrm{C} 10(4 \mathbf{c})$ into a dimerized

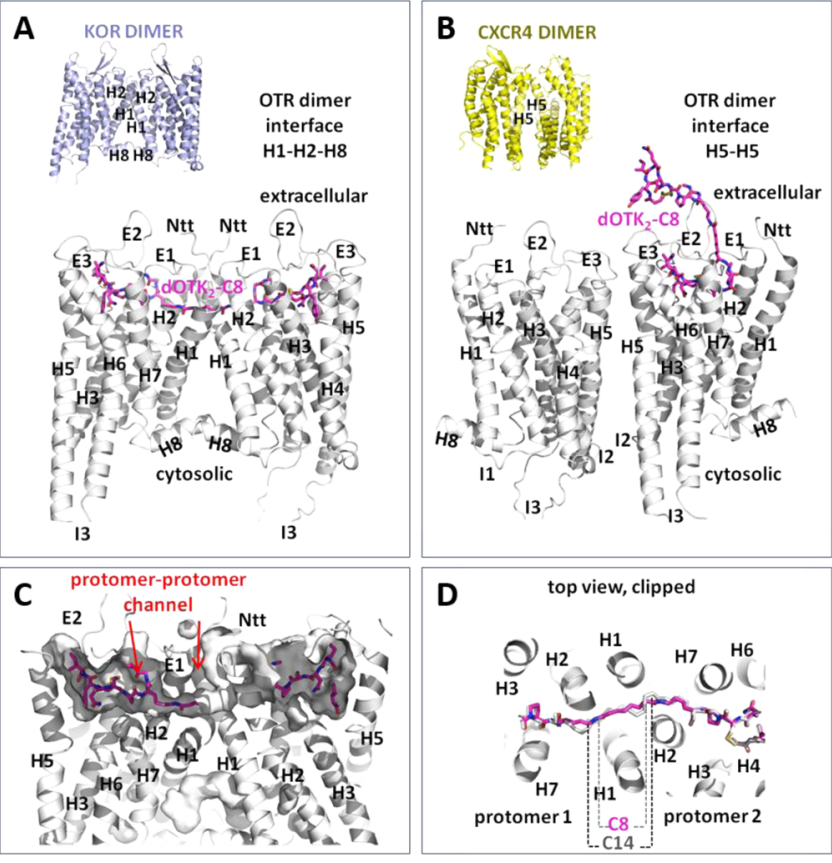

Figure 5. Structural homology model of the OTR dimer interfaces and docking of the bivalent $\mathrm{dOTK}_{2}-\mathrm{C} 8$ (4b). (A) OTR dimers with a putative TMH1-TMH2-helix8 interface. Crystal structures of $\kappa$-opioid receptor (KOR), $\beta-1$ adrenergic receptor, and opsin suggest a protomer-protomer arrangement with a contact interface among TMH1-TMH2-helix8. The dimeric-conformation of the $\kappa$-opiod receptor (PDB entry 4DJH, insert window) was used to build the OTR dimer with a TMH1-TMH2-helix8 interface. This arrangement provides a suitable model to dock both moieties of the homobivalent ligand into the orthosteric binding-sites. (B) A hypothetical OTR TMH5-TMH6-ICL2 dimer arrangement, suggested by the crystallized CXCR4 dimer (insert window, yellow backbone), did not allow for the docking of the two moieties of $\mathrm{dOTK}_{2}-\mathrm{C} 8(\mathbf{4 b})$ into the putative orthosteric binding sites. (C) The side-chains of dOTK moieties at position 8 engage into a channel-like opening between TMH1 and TMH2 (inner surface, clipped), and the C 8 spacer runs into a channellike protomer-protomer connection. (D) In contrast to C8 (magenta sticks), extended spacers such as C14 (gray) would not sterically fit between the interacting helices of the OTR. In a constrained constellation in which the protomer-protomer distance is held during dynamic movement of the C14 spacer only, the benched C14 spacer is unable to engage the channel opening at the interacting helices. $\mathrm{H}$, helix; Ntt, N-terminal tail; E, extracellular loop.

OTR appear possible: any connection between the binding sites external to TMHs would have required a much longer spacer. The OTR/dOTK arrangement in the TMH1-TMH2helix8 dimer is also supported by the fact that the C6 spacer is too short, leading to an extraction of the ligand-moieties from the orthosteric binding sites in the protomers. Likewise, by constraining ligand moieties with the $\mathrm{C} 12$ and $\mathrm{C} 14$ spacers inside the orthosteric binding sites, the conformation of the spacers within the channel would become kinked (Figure 5D), suggesting that their excessive length could prevent appropriate binding at the dimer by steric hindrance. A model based on TMH5-TMH6 (Figure 5B) will also require a much longer spacer, as the estimated straight linear distance between the two orthosteric binding sites is, in this case, approximately $50 \AA$; however, as the spacer would lay above the ECLs regions, its length will need to be further increased, with a high probability that a very long alkane chain will negatively impact docking and binding for its higher hydrophobicity. 
Our modeling predicted that receptor mutations of the dimeric TMH1-TMH2-helix8 interface and/or synthetic peptides mimicking TMH1 would interfere with a channel constitution, altering the critical relationship between the channel length and the length of the $\mathrm{C} 8$ and $\mathrm{C} 10$ spacers. If either were altered, then we predicted this would abolish the reduced entropic cost linked to the favorable docking, resulting in the loss of superactivity. Experimentally, if unable to dock into the two orthosteric sites of a receptor dimer, we expect the C8 and C10 bivalent ligands to lose the first, high potency phase of the activation curve. To specifically test this hypothesis, we used a series of point mutations in the TMH1-TMH2-helix8 interface of OTR dimers and synthetic peptides interfering with the TMH1 and TMH5 dimer interfaces.

Point Mutations at the TMH1 Dimer Interface and a Synthetic Peptide Mimicking TMH1 Modifies the Activation Induced by Bivalent dOTK Ligands. Receptors bearing single or combined mutations of all residues exposed at the TMH1-TMH2-helix8 interface (C47, V43, L50, L51, L97, L98, V341, and V345) were preliminarily evaluated for their expression at the cell surface by fluorescence microscopy assays (Figure S2) and FACS analysis (Figure S3). We found that receptors bearing multiple mutations at the TMH1-TMH2helix8 interface were retained inside the intracellular compartments. Only, the OTR C47A and OTR V43A/C47A receptor mutants were found to be correctly localized and expressed at the plasma membrane where they formed dimers (Figure S4) and were further characterized.

The OTR C47A and OTR V43A/C47A (Figure 6A) were probed with the full $\mathrm{C} 6-\mathrm{C} 14$ bivalent series $(\mathbf{4 a}-\mathbf{e})$ (Figure $6 \mathrm{~B}, \mathrm{C})$. In the OTR C47A, the C6, C8, and C10 bivalent ligands presented monophasic activation curves (Hill coefficient different from $-1, P<0.05)$, all rightward shifted with respect to that of dOTK (2) (Table 2). Intriguingly, the bivalent ligands with longer spacers, $\mathrm{C} 12$ (4d) and C14 (4e), displayed a biphasic trend at this mutant, with a calculated $\mathrm{EC}_{50 \mathrm{Hi}}<10$ $\mathrm{pM}$ and $\mathrm{EC}_{50 \mathrm{Lo}}>100 \mathrm{nM}$ (Figure $6 \mathrm{~B}$ and Table 2). In the OTR mutant V43A/C47A, only the bivalent ligand with the longest spacer, $\mathrm{dOTK}_{2}-\mathrm{C} 14(4 \mathrm{e})$, activated $\mathrm{Gq}$ with a biphasic curve with calculated $\mathrm{EC}_{50 \mathrm{Hi}}$ of $11 \pm 14 \mathrm{pM}(\mathrm{SE})$ and $\mathrm{EC}_{50 \mathrm{Lo}}$ of $867 \pm 250 \mathrm{nM}(\mathrm{SE})$ (Figure 6C and Table 2). These data suggest that perturbing the TMH1-TMH2-helix 8 interface and the spacer channel opening between the helices at residues $\mathrm{C} 47$ and V43 "relaxes" or "stretches" the dimers allowing enhanced binding and functional activity of bivalent analogues with increased spacer lengths but excludes the biphasic effects of C8 (4b) and C10 (4c) observed in the OTR wild type (WT). We conclude that these two point mutations most likely lead to a weakening in protomer-protomer interactions with a consequent rearrangement between the protomers which, in turn, causes a shift in the spacer-length required to enable the binding of two dOTK pharmacophores into both orthosteric sites.

To ensure that these results are indeed due to proteinprotein interactions, we used synthetic peptides mimicking single transmembrane helices, an approach previously shown to destabilize in vitro and in vivo the quaternary structure and the interaction interfaces of heterodimeric $\mathrm{GPCR}^{44-48}$ and rhodopsin. ${ }^{49}$ Cells were incubated with TMH1 and TMH5 peptides fused at their C-terminal end with a portion of the HIV transactivator of transcription (TAT) sequences to
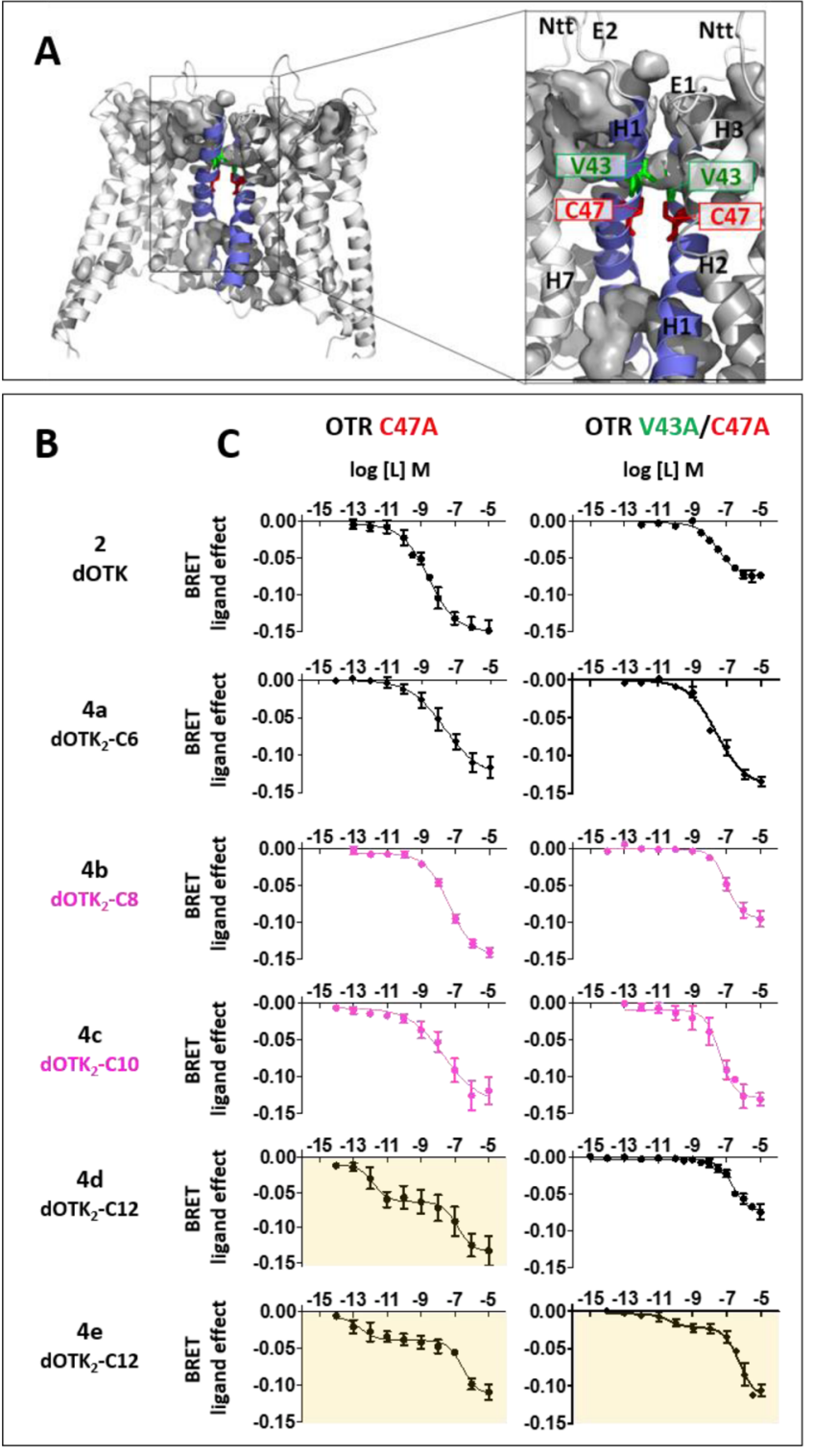

Figure 6. Functional properties of monovalent and bivalent analogues at C47A and V43A/C47A OTR mutants at the dimeric TMH1/ TMH2 OTR interface. (A) The OTR dimer model reveals potential protomeric contacts constituted by hydrophobic amino acids mainly located between TMH1 and TMH2, respectively. Valine in position 43 (V43, in green) and cysteine in position 47 (C47, in red) both localized on TMH1 are reported in the inset. H, helix; E, extracellular loop; $\mathrm{Ntt}, \mathrm{N}$-terminal tail. (B) Gq activation was measured by BRET in HEK293 cells coexpressing G $\alpha_{\mathrm{q}}-\mathrm{RLuc} 8, \mathrm{GFP}^{10}-\mathrm{G} \gamma_{2}, \mathrm{G} \beta_{1}$, and C47A or (C) V43A/C47A OTR mutants. Cells were left untreated or stimulated with increasing concentrations of the indicated agonists. Data are expressed as the difference in the BRET signal measured in the absence and presence of the agonist and are shown as the means \pm SEM of three-four independent experiments performed in triplicate. The background of graphs reporting biphasic responses is colored in light-orange. Bivalent $\mathrm{dOTK}_{2}-\mathrm{C} 8$ (4b) and $\mathrm{dOTK}_{2}-\mathrm{C} 10$ (4c) activation curves are in magenta.

promote their integration and correct orientation in the plasma membrane. ${ }^{50}$

First, we tested the interference of TMH1 and TMH5 (Figure 7A) with the OTR dimer formation/stabilization in cells transfected with OTR-GFP ${ }^{2}$ and OTR-Rluc (Figure 7B). As shown in Figure $7 \mathrm{~B}$, incubation with TMH1-TAT and 
Table 2. Characterization of Monovalent and Bivalent Ligands Function at C47A and V43A/C47A OTR Mutants ${ }^{a}$

\begin{tabular}{|c|c|c|c|c|}
\hline & $\mathrm{EC}_{50}($ mean $\pm \mathrm{SE})$ & Hill coefficient $($ mean $\pm S E)$ & $E_{\max }($ mean $\pm S E)$ & $n$ \\
\hline \multicolumn{5}{|l|}{ C47A } \\
\hline dOTK (2) & $2.8 \pm 0.7 \mathrm{nM}$ & $-0.54 \pm 0.10$ & $-0.15 \pm 0.008$ & 3 \\
\hline $\mathrm{dOTK}_{2}-\mathrm{C} 6(\mathbf{4 a})$ & $21.9 \pm 18.3 \mathrm{nM}$ & $-0.43 \pm 0.12$ & $-0.13 \pm 0.01$ & 3 \\
\hline $\mathrm{dOTK}_{2}-\mathrm{C} 8(\mathbf{4 b})$ & $40.5 \pm 9.4 \mathrm{nM}$ & $-0.61 \pm 0.07$ & $-0.14 \pm 0.006$ & 3 \\
\hline $\mathrm{dOTK}_{2}-\mathrm{C} 10(4 \mathrm{c})$ & $21.7 \pm 85 \mathrm{nM}$ & $-0.42 \pm 0.12$ & $-0.14 \pm 0.019$ & 3 \\
\hline \multirow[t]{2}{*}{$\mathrm{dOTK}_{2}-\mathrm{C} 12(\mathbf{4 d})$} & $\mathrm{EC}_{50 \mathrm{Hi}} 1.2 \pm 0.7 \mathrm{pM}$ & fixed -1 & $-0.13 \pm 0.012$ & 3 \\
\hline & $\mathrm{EC}_{50 \mathrm{Lo}} 135 \pm 53.6 \mathrm{nM}$ & fixed -1 & & \\
\hline \multirow[t]{2}{*}{$\mathrm{dOTK}_{2}-\mathrm{C} 14(\mathbf{4 e})$} & $\mathrm{EC}_{50 \mathrm{Hi}} 1.4 \pm 3.5 \mathrm{pM}$ & fixed -1 & $-0.11 \pm 0.008$ & 3 \\
\hline & $\mathrm{EC}_{50 \mathrm{Lo}} 301 \pm 194 \mathrm{nM}$ & fixed -1 & & \\
\hline \multicolumn{5}{|l|}{ V43A/C47A } \\
\hline dOTK (2) & $33.4 \pm 11 \mathrm{nM}$ & $-0.73 \pm 0.11$ & $-0.08 \pm 0.003$ & 3 \\
\hline $\mathrm{dOTK}_{2}-\mathrm{C} 6(\mathbf{4 a})$ & $25.6 \pm 9.8 \mathrm{nM}$ & $-0.53 \pm 0.14$ & $-0.14 \pm 0.013$ & 3 \\
\hline $\mathrm{dOTK}_{2}-\mathrm{C} 8(\mathbf{4 b})$ & $117.2 \pm 44.9 \mathrm{nM}$ & $-0.78 \pm 0.19$ & $-0.10 \pm 0.007$ & 3 \\
\hline $\mathrm{dOTK}_{2}-\mathrm{C} 10(4 \mathrm{c})$ & $40.55 \pm 18.5 \mathrm{nM}$ & $-0.66 \pm 0.20$ & $-0.14 \pm 0.013$ & 3 \\
\hline $\mathrm{dOTK}_{2}-\mathrm{C} 12(4 \mathrm{~d})$ & $182 \pm 30.6 \mathrm{nM}$ & $-0.78 \pm 0.16$ & $-0.08 \pm 0.006$ & 4 \\
\hline \multirow[t]{2}{*}{$\mathrm{dOTK}_{2}-\mathrm{C} 14(4 \mathrm{e})$} & $\mathrm{EC}_{50 \mathrm{Hi}} 11 \pm 14 \mathrm{pM}$ & fixed -1 & $-0.11 \pm 0.007$ & 4 \\
\hline & $\mathrm{EC}_{50 \mathrm{Lo}} 867 \pm 250 \mathrm{nM}$ & fixed -1 & & \\
\hline
\end{tabular}

${ }^{a}$ Parameters obtained in BRET experiments (Figure 6) describe the activity of monovalent and bivalent agonists on Gq signaling in mutant OTRs. Data were analyzed by a four-parameter logistic model for monotonic curves or by a seven parameter model for biphasic curves. For biphasic fitting, the Hill coefficient was fixed equal to -1 for both phases, $\mathrm{EC}_{50 \mathrm{Hi}}$ refers to the "high" potency site, and $\mathrm{EC}_{50 \mathrm{Lo}}$ to the "low" potency site. Estimated parameter values represent the mean $\pm S E$ of three-four independent experiments performed at least in triplicate.

TMH5-TAT resulted in a reduction of the maximal BRET of $36 \%$ and $30 \%$, indicating that both peptides induced a destabilization of the OTR dimers/oligomers. The residual BRET signal observed in the presence of both TMH1-TAT and TMH5-TAT is consistent with the coexistence of two dimeric subpopulations characterized by a TMH1 or a TMH5 interface; in addition, it is likely that the peptides disrupt the quaternary structure between the receptors but do not necessarily block dimerization completely. Thus, a component of this residual maximal BRET could arise from dimeric/oligomeric receptors that cannot be modulated by exogenous peptides, such as those residing in intracellular compartments. Importantly, there was no measurable decrease in the BRET signal in the presence of a control transmembrane peptide TMH1C-TAT, in which all residues exposed to the putative interacting interface of TMH1 have been changed into alanine. These results confirm the specificity of the functional interference exerted by the TMH1TAT and TMH5-TAT peptides on OTR dimers/oligomers.

Next, we tested the effects of the bivalent ligands in the presence of TMH1-TAT or TMH5-TAT. If the superagonist effects were indeed due to binding to two separate receptors in a dimer, then disruption of the quaternary structure with the disrupting peptides should lead to a monophasic response curve. If, however, the bivalent ligands are binding to two sites on the same receptor or binding a single receptor in a novel orthosteric site (Figure 4D panel V), then the peptides should have no effect on the response curve. As shown in Figure 7C, the addition of TMH1-TAT completely disrupts the biphasic response of bivalent ligands which now present monophasic $(P$ $<0.05$ ) activation curves (Hill coefficient in the range 0.410.59; Table 3). Moreover, the $\mathrm{EC}_{50}$ values were all rightward shifted with respect to that of dOTK (2) (Table 3). On the contrary, no effect of TMH5-TAT was observed on the biphasic response $(P<0.05)$ of the activation curves (Figure $7 \mathrm{D})$ and on activation parameters (Table 3 ) of bivalent ligands. Finally, neither TMH1 nor TMH5 affected the activation properties of the monovalent dOTK (2) ligand.
These data solidify the model presented in Figure 4 and demonstrate that the high affinity state of the OTR targeted by the $\mathrm{C} 8(\mathbf{4 b})$ and $\mathrm{C} 10(\mathbf{4 c})$ bivalent analogues are the dimers having a TMH1/TMH2 interface.

Potency of $\mathrm{dOTK}_{2}-\mathrm{C} 8$ in Vivo on Social Behavior. OTR agonists are currently in clinical trial for autism related disorders. ${ }^{51}$ To test whether a bivalent OTR ligand may be clinically relevant, we tested $\mathrm{dOTK}_{2}-\mathrm{C} 8(\mathbf{4 b})$ in vivo in two animal models in which the pharmacological effects of OT agonists on social behavior have been previously extensively characterized.

The first model is represented by genetically modified mice in which one allele coding for the mouse OTR gene (Oxtr) has been deleted; as previously reported, $\mathrm{Oxtr}^{+/-}$mice display a deficit in social behavior. ${ }^{52}$ In particular, when tested for sociability in the three chamber test (Figure $8 \mathrm{~A}$ ), these animals spent an equal amount of time exploring the compartment occupied by a stranger mouse and that occupied by an empty cage, with a resulting difference score, calculated as the difference between the time spent in the chamber with the stranger and the time spent in the chamber with the empty cage, close to zero (Figure $8 \mathrm{~B}$ and $\mathrm{C}$ ). As previously reported, ${ }^{52}$ a single dose of OT $(\mathbf{1})$ of $0.5 \mathrm{ng} /$ mouse administered i.c.v. immediately prior to the test corrected this abnormal behavior by significantly increasing the time spent exploring the stranger mouse over the time spent exploring the empty cage, as indicated by a significant increase in the difference score [OT (1): $\mathrm{F}(3,36)=20.53, P<0.001]$ (Figure $8 \mathrm{~B}$ ). To assess the effects of $\mathrm{dOTK}_{2}-\mathrm{C} 8(4 \mathrm{~b})$ on social behavior, we administered this compound i.c.v. to male $\mathrm{Oxtr}^{+/-}$mice. As shown in Figure $8 \mathrm{C}$, $\mathrm{dOTK}_{2}-\mathrm{C} 8$ (4b) significantly restored sociability, i.e., significantly increased the time spent exploring the unfamiliar mouse over the time spent exploring the empty cage, already at a dose of $0.005 \mathrm{ng} /$ mouse $\left[\mathrm{dOTK}_{2}-\mathrm{C} 8(4 \mathrm{~b}): \mathrm{F}(3,36)=14.16\right.$, $P<0.001]$. The dose of $0.05 \mathrm{ng} /$ mouse was statistically different from $0.005 \mathrm{ng} /$ mouse $(P<0.05)$ but not from $0.5 \mathrm{ng} /$ mouse. These data indicate that $\mathrm{dOTK}_{2}-\mathrm{C} 8$ is active at a 100 - 
A TMU 1 ALARVEVAVICLIILLALISGNACVLLALRT-TAT TWMIת 5 KAYITWITLAVYIVPVIVIAACYGLISFKIWQ-TAI TMH 1C aLAAVEaAvLAa

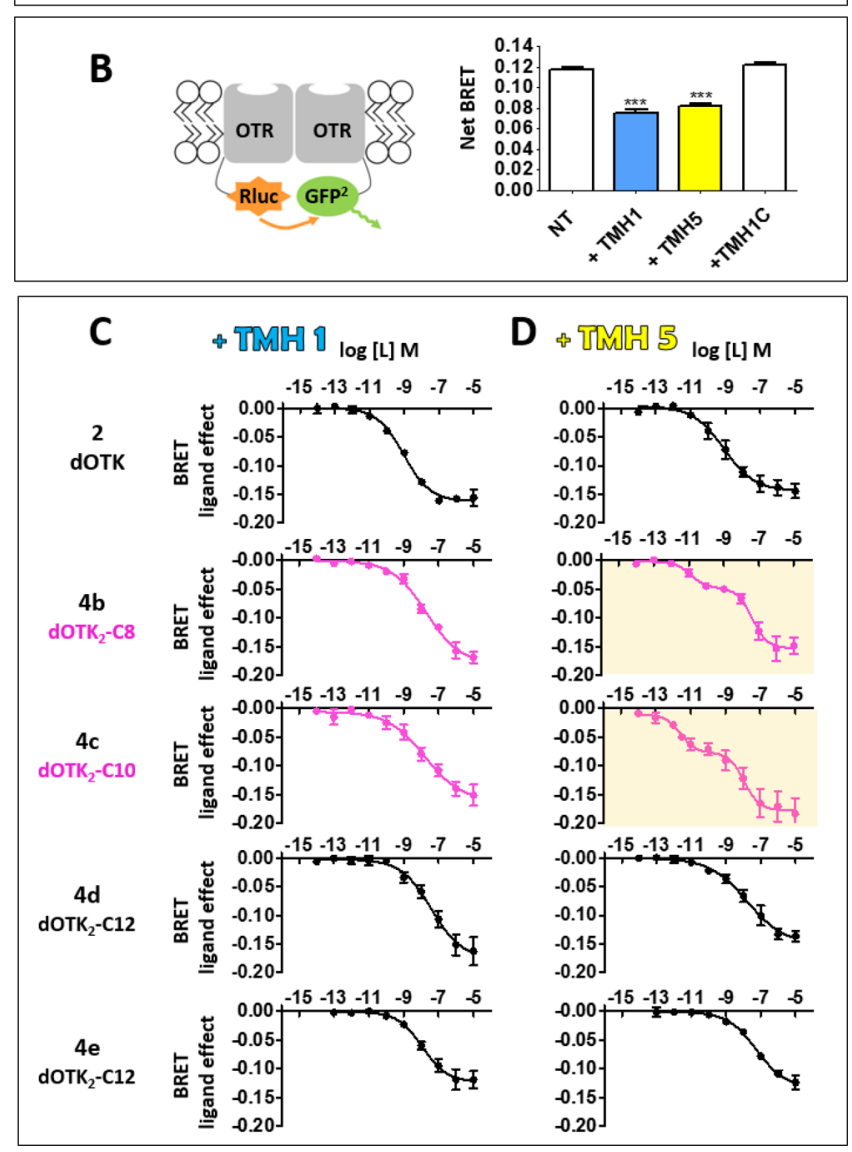

Figure 7. Interference properties of synthetic transmembrane peptides on OTR homodimerization and activation. (A) Primary sequence of OTR transmembrane (TMH1 and TRMH5) synthetic peptides Cterminally fused to a portion of the highly polar HIV transactivator of transcription (TAT, in red) (GRKKRRQRRR). TMH 1C, in which all residues exposed to the putative interacting interface of TMH1 have been changed into alanine, was used as the control. (B) To test synthetic transmembrane peptide effects on OTR homodimerization, cells were transfected with OTR-Rluc $(3 \mu \mathrm{g})$ and OTR-GFP ${ }^{2}(9 \mu \mathrm{g})$ and incubated with the indicated TMHs used at $1 \mu \mathrm{M}$ for $1 \mathrm{~h}$. Values are represented as the means \pm SEM of at least three independent experiments. $* * * P<0.001$ versus the corresponding not treated (NT) cells. (C) Gq activation was measured by BRET in HEK293 cells coexpressing $\mathrm{G} \alpha \alpha_{\mathrm{q}}-\mathrm{RLuc8}, \mathrm{GFP}^{10}-\mathrm{G} \gamma_{2}, \mathrm{G} \beta_{1}$, and OTR. Cells were preincubated with $1 \mu \mathrm{M}$ TMH1 or (D) $1 \mu \mathrm{M}$ TMH5 for $2 \mathrm{~h}$ and then left untreated or stimulated with increasing concentrations of the indicated agonists. Data are expressed as the difference in the BRET signal measured in the absence and presence of the agonist and are shown as the means \pm SEM of three to four independent experiments performed in triplicate. The background of graphs reporting biphasic responses is colored in light-orange. Bivalent $\mathrm{dOTK}_{2}-\mathrm{C} 8(\mathbf{4 b})$ and $\mathrm{dOTK}_{2}-\mathrm{C} 10(4 \mathrm{c})$ activation curves are in magenta.

fold lower dose in comparison to that of the endogenous peptide OT in restoring sociability in $\mathrm{Oxtr}^{+/-}$mice.

The second model is represented by the shoaling behavior of zebrafish, a social behavior that we have previously shown to be modulated, in this vertebrate, by several OT-related peptides ${ }^{53}$ (Figure 8D). We demonstrated that the total time spent by WT zebrafish swimming parallel to conspecifics is greater than that spent shoaling in proximity of Nacre, a mutant zebrafish with a defect in pigmentation. When this parameter was expressed as a difference in the time spent by the test animal with each phenotype (Nacre-WT), it was negative in vehicle treated animals. As shown in Figure $8 \mathrm{E}$ and as previously reported, ${ }^{53}$ treatment with isotocin (IT), the analogue of OT in fish, injected into the caudal musculature significantly increased the time spent in proximity to Nacre at a concentration of $0.75 \mathrm{ng} /$ $\mathrm{kg}$, with a consequent significant decrease in the difference in the time (Nacre-WT) that becomes positive, indicating that the fish prefer to shoal in proximity to Nacre than to WT [IT: $\mathrm{F}(4,45)=34.00, P<0.001]$.

As shown in Figure $8 \mathrm{~F}, \mathrm{dOTK}_{2}-\mathrm{C} 8$ (4b) significantly increased the shoaling preference to $\mathrm{Nacre}$, i.e., significantly increased the time spent swimming parallel to Nacre over the time spent shoaling close to the conspecific already at a dose of $0.02 \mathrm{ng} / \mathrm{kg}[\mathrm{F}(6,63)=17.78, P<0.0001]$. The dose of $0.2 \mathrm{ng} /$ $\mathrm{kg}$ was statistically different from the lower doses 0.002 and $0.02 \mathrm{ng} / \mathrm{kg}$ but not from $0.5,0.75$, and $1 \mathrm{ng} / \mathrm{kg}$. These data indicate that $\mathrm{dOTK}_{2}-\mathrm{C} 8(\mathbf{4 b})$ is active at approximately a $40-$ fold lower dose as compared to the endogenous peptide IT on zebrafish sociability in vivo. The slightly lower potency of $\mathrm{dOTK}_{2}-\mathrm{C} 8(\mathbf{4 b})$ in zebrafish compared to that of mice can be ascribed either to the differences between the involved zebrafish receptor (native ligand IT) and the mouse receptor (native ligand OT (1)) across species and/or to the administration route employed $\left(\mathrm{dOTK}_{2}-\mathrm{C} 8(\mathbf{4 b})\right.$ was administered i.c.v. in mice and i.m. in zebrafish).

\section{DISCUSSION}

Despite the promise of GPCR dimers as drug targets, clinically relevant molecules specific to homo-oligomers have not yet been reported. In this study, we report the synthesis and characterization of a series of homobivalent agonistic ligands in which two identical oxytocin-derived peptides were linked by aliphatic spacers of increasing length. Using this series of compounds, we are able to show that (i) the OTR exists in both low affinity and high affinity states that most likely reflect changes in oligomeric assembly; (ii) the low affinity site is indifferent to the spacer length of the bivalent ligands; (iii) the high affinity population achieves superagonistic responses upon binding of bivalent ligands having a specific spacer length (C8$\mathrm{C} 10 ; \sim 25 \AA)$, indicating the presence of a receptor entity with a specific structure; (iv) mutagenesis and TMH interference assays experimentally show that this structure is represented by homodimes interacting via a TMH1-TMH2 interface; and (v) dimeric OTR can be exploited in vivo as a drug target of homobivalent based therapeutic strategies.

The development of bivalent ligands such as those shown here requires matching the spacer lengths of bivalent ligands with the distance between the receptor protomers. In the OTR, this effect is dependent on the proposed "channel-like passage", which determines and constrains the length of the bivalent spacer and prevents biphasic activation for bivalent analogues with shorter or longer spacers. This channel-like passage is a feature that emerges in the model only when a specific dimeric arrangement based on a TMH1-TMH2 interface is adopted; the relevance of the channel and involvement of the TMH1 interface in an active dimeric conformation targeted by bivalent ligands was predicted by our modeling data indicating that modification of single residues located in TMH1 prevent bivalent docking into the OTR dimer. This model has been 
Table 3. Characterization of Monovalent and Bivalent Ligands Function in the Presence of Interfering TMH1-TAT and TMH5TAT Peptides ${ }^{a}$

\begin{tabular}{|c|c|c|c|c|}
\hline & $\mathrm{EC}_{50}($ mean $\pm \mathrm{SE})$ & Hill coefficient $($ mean $\pm S E)$ & $E_{\max }($ mean $\pm \mathrm{SE})$ & $n$ \\
\hline \multicolumn{5}{|l|}{ +TMH1 } \\
\hline dOTK (2) & $0.92 \pm 0.3 \mathrm{nM}$ & $-0.57 \pm 0.07$ & $-0.15 \pm 0.005$ & 3 \\
\hline $\mathrm{dOTK}_{2}-\mathrm{C} 8(4 \mathbf{b})$ & $19.3 \pm 9.1 \mathrm{nM}$ & $-0.44 \pm 0.07$ & $-0.16 \pm 0.011$ & 4 \\
\hline $\mathrm{dOTK}_{2}-\mathrm{C} 10(4 \mathrm{c})$ & $17.3 \pm 16.1 \mathrm{nM}$ & $-0.41 \pm 0.12$ & $-0.15 \pm 0.018$ & 4 \\
\hline $\mathrm{dOTK}_{2}-\mathrm{C} 12(4 \mathrm{~d})$ & $37.9 \pm 12.1 \mathrm{nM}$ & $-0.49 \pm 0.14$ & $-0.16 \pm 0.018$ & 3 \\
\hline $\mathrm{dOTK}_{2}-\mathrm{C} 14(4 \mathrm{e})$ & $15.4 \pm 6.3 \mathrm{nM}$ & $-0.59 \pm 0.20$ & $-0.144 \pm 0.009$ & 3 \\
\hline \multicolumn{5}{|l|}{ +TMH5 } \\
\hline dOTK (2) & $0.75 \pm 0.3 \mathrm{nM}$ & $-0.49 \pm 0.12$ & $-0.14 \pm 0.008$ & 3 \\
\hline \multirow[t]{2}{*}{$\mathrm{dOTK}_{2}-\mathrm{C} 8(4 \mathrm{~b})$} & $\mathrm{EC}_{50 \mathrm{Hi}} 11.8 \pm 11.1 \mathrm{pM}$ & fixed -1 & $-0.15 \pm 0.002$ & 3 \\
\hline & $\mathrm{EC}_{50 \mathrm{Lo}} 33.4 \pm 11.9 \mathrm{nM}$ & fixed -1 & & \\
\hline \multirow[t]{2}{*}{$\mathrm{dOTK}_{2}-\mathrm{C} 10(4 \mathrm{c})$} & $\mathrm{EC}_{50 \mathrm{Hi}} 2.57 \pm 1.5 \mathrm{pM}$ & fixed -1 & $-0.17 \pm 0.016$ & 3 \\
\hline & $\mathrm{EC}_{50 \mathrm{Lo}} 11.0 \pm 3.4 \mathrm{nM}$ & fixed -1 & & \\
\hline $\mathrm{dOTK}_{2}-\mathrm{C} 12(4 \mathrm{~d})$ & $14.0 \pm 9.9 \mathrm{nM}$ & $-0.40 \pm 0.10$ & $-0.15 \pm 0.019$ & 4 \\
\hline $\mathrm{dOTK}_{2}-\mathrm{C} 14(\mathbf{4 e})$ & $59.0 \pm 23.1 \mathrm{nM}$ & $-0.47 \pm 0.11$ & $-0.145 \pm 0.011$ & 3 \\
\hline
\end{tabular}

${ }^{a}$ Parameters obtained in BRET experiments (Figure 7) describe the activity of monovalent and bivalent agonists on Gq signaling in wild-type OTRs in the presence of synthetic transmembrane peptides fused to the TAT peptide. Data were analyzed by a four-parameter logistic model for monotonic curves or by a seven-parameter model for biphasic curves. For biphasic fitting, the Hill coefficient was fixed equal to -1 for both phases, $\mathrm{EC}_{50 \mathrm{Hi}}$ refers to the "high" potency site and $\mathrm{EC}_{50 \mathrm{Lo}}$ to the "low" potency site. Estimated parameter values represent the mean $\pm \mathrm{SE}$ of three-four independent experiments performed at least in triplicate.

validated by interference experiments with synthetic peptides mimicking transmembrane helices and mutagenesis data of key residues located at the TMH1-TMH2 interface in which we observed a loss of the superagonist effects of $\mathrm{dOTK}_{2}-\mathrm{C} 8(4 \mathbf{b})$ and $\mathrm{dOTK}_{2}-\mathrm{C} 10(4 \mathrm{c})$ but a gain in the superagonist effects of $\mathrm{dOTK}_{2}-\mathrm{C} 12(4 \mathrm{~d})$ and $\mathrm{dOTK}_{2}-\mathrm{C} 14(4 \mathrm{e})$. This behavior is coherent with a weakening in the TMH1 protomer-protomer interactions induced by these mutations, which may include mutual azimuthal rotation. The channel passage described here could be of general interest: the search and characterization of channel-like opening(s) might be an important step in the design of superactive bivalent ligands for other members of the GPCR superfamily, with broad applications for drug design and development.

A key question concerns the mechanism responsible for the boost in $\mathrm{EC}_{50 \mathrm{Hi}}$ observed for the superactive bivalent ligands docking into the TMH1-TMH2 dimer. A reduction in the entropy cost for bivalent ligands (and an increase in binding affinity) is expected when their two pharmacophores, connected by a spacer of length $L$, are both able to bind to the docking sites of a dimeric receptor. ${ }^{54,55}$ Indeed, the docking of the first pharmacophore constrains the second one within a volume $(V)$ that could be roughly approximated as a hemisphere of radius $L$. Here, $L \approx 25 \AA$, is the distance between the $\mathrm{C}$-alpha atoms of the two lysine residues present in $\mathrm{dOTK}_{2}-\mathrm{C} 8(\mathbf{4 b})$ and thus includes the C8 spacer plus the lateral chains of the two lysine residues (Figure 1 and Figure 4D). Inside $V$, the effective local concentration $\left(C_{\mathrm{LOC}}\right)$ of the unbound pharmacophore is roughly $C_{\mathrm{LOC}} \approx 50 \mathrm{mM}$. Since at such high concentrations the second pharmacophore becomes fully bound to the receptor, the condition of single pharmacophore binding of a bivalent ligand to a dimeric receptor is unstable. This effect can be formally expressed in terms of a reduced entropy cost for the binding of bivalent ligands, leading to a markedly enhanced binding affinity. Its analysis also enables the formulation, under a few simplifying assumption, of a simple expression for the expected activation efficiency of bivalent ligand: $\mathrm{EC}_{50 \mathrm{Hi}} \sim\left(\mathrm{EC}_{50 \mathrm{Lo}}\right)^{2} / C_{\mathrm{LOC}}$ (Supporting Note 2). This simple estimate is verified by our data, supporting the notion that the huge increase in potency intrinsically brought about by the double docking is the dominant factor in our observations, overshadowing other effects of less quantitative relevance.

Emerging data indicate that in GPCRs different interfaces can be found in different oligomers and even in different conformations (activity states) of the same oligomer., ${ }^{3,35}$ For example, molecular simulation of $\beta 1$ - and $\beta 2$-adrenergic receptor homodimer stability in a lipid bilayer is consistent with a model of oligomerization in which more stable TMH1 homodimers diffuse through the membrane, transiently interacting with other protomers at interfaces involving other TMH helices (e.g., TMH4). ${ }^{56}$ The data obtained in this work suggest that the OTR also exists in at least two dimeric conformations, one involving a TMH1/TMH2 interface and the other a TMH5 interface, and that only the TMH1/TMH2 dimers can be activated by the bivalent ligands with increased affinity and potency. Importantly, the analysis of the amplitude of the first phase of the $\mathrm{dOTK}_{2}-\mathrm{C} 8(\mathbf{4 b})$ and $\mathrm{dOTK}_{2}-\mathrm{C} 10$ (4c) biphasic activation curves allowed for the computation of the fraction of the TMH1/TMH2 dimeric OTR specifically targeted by the bivalent compounds. The amplitude of the first phase of the $\mathrm{dOTK}_{2}-\mathrm{C} 8(\mathbf{4 b})$ and $\mathrm{dOTK}_{2}-\mathrm{C} 10$ (4c) biphasic curves, expressed as the percentage of the maximal amplitude of the curve $\left(E_{\max }\right.$ values reported in Table 2), resulted in $32 \pm$ $0.5 \%$ (SE) and $44 \pm 0.5 \%$ (SE), suggesting that, in our experimental conditions, the dimeric OTR population targeted by the superactive bivalent ligand ranges between 32 and $44 \%$ of all activable OTR present in the cells, a percentage in line with previous single molecule attempts to measure oligomerization. $^{57,58}$ To quantitatively disclose dimeric entities in living cells is currently a very critical issue in the GPCR field as the techniques employed to determine the composition of monomeric/oligomeric GPCRs, including resonance energy transfer (RET), fluorescence lifetime imaging (FLIM), total internal reflected fluorescence (TIRF), fluorescence recovery after photobleaching (FRAP), and fluorescence correlation spectroscopy (FCS), have led to a variety of different results, 

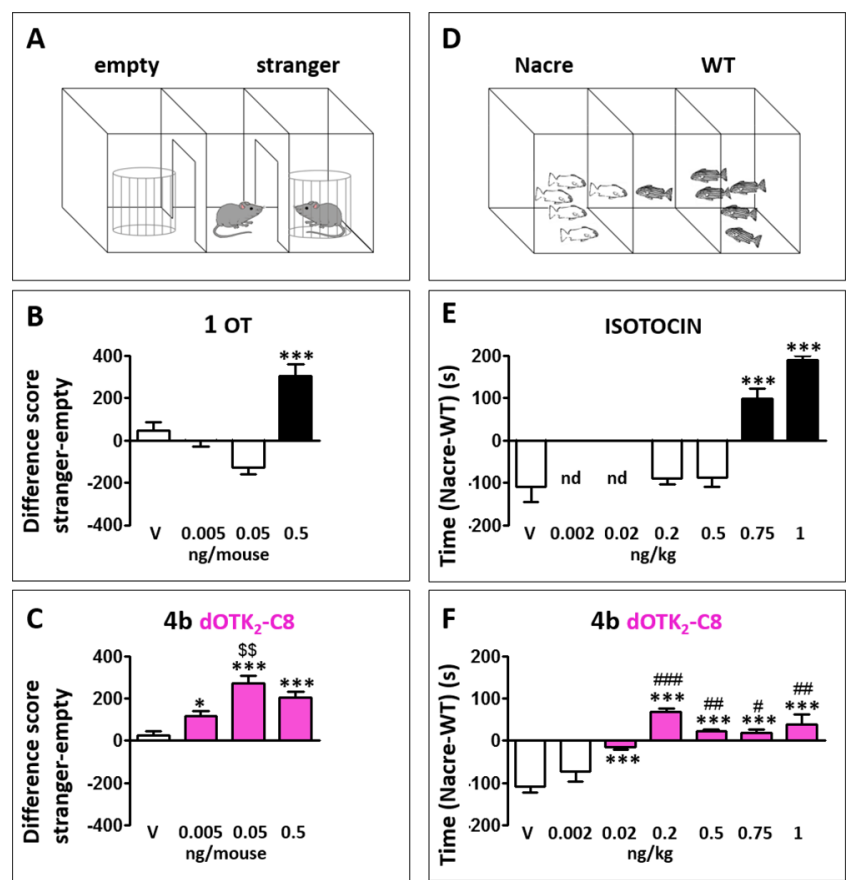

Figure 8. Bivalent $\mathrm{dOTK}_{2}-\mathrm{C} 8$ peptide boosts social behavior in mice and zebrafish. (A) Effect of OT (1) and $\mathrm{dOTK}_{2}-\mathrm{C} 8$ (4b) on sociability in $\mathrm{Oxtr}^{+-}$mice assayed in the three chamber apparatus. Sociability (expressed as the difference score between the time spent in proximity to a stranger and the empty cage) was evaluated $10 \mathrm{~min}$ following i.c.v. injection of vehicle $(\mathrm{V})$ or increasing doses (ng/mouse) of (B) OT (1) or (C) dOTK $2-$ C8 (4b). (D) Effect of isotocin and $\mathrm{dOTK}_{2}-\mathrm{C} 8(\mathbf{4 b})$ on social preference in zebrafish evaluated in a shoaling preference test. Social preference is expressed in terms of difference score between the time spent close to Nacre and that spent in proximity to conspecific by the WT test fish. (E) Isotocin and (F) $\mathrm{dOTK}_{2}-\mathrm{C} 8(\mathbf{4 b})$ were injected i.m. immediately prior to acclimatization. Values are represented as the means \pm SEM of at least 10 animals in each group. $* P<0.05$; $* * * P<0.001$ versus the corresponding vehicle group. $\$ \$ P<0.005$ versus the $0.05 \mathrm{ng}$ of dose in mice; \#\#\# $P$ $<0.001$ and \#\# $P<0.05$ versus the $0.2 \mathrm{ng} / \mathrm{kg}$ dose in zebrafish (oneway ANOVA followed by Bonferroni's posthoc test); ns, not significant; nd, not determined.

with no apparent consensus on what equilibrium among these forms should be expected for each GPCR. ${ }^{3}$

Finally, to demonstrate the translational value of the superactive OT analogues we used two well-established in vivo models (social behavior in zebrafish and mice) showing that the homobivalent $\mathrm{dOTK}_{2}-\mathrm{C} 8$ (4b) ligand displays a significant gain (40- and 100-folds) over the endogenous ligands, IT and OT (1). The increased potency of $\mathrm{dOTK}_{2}-\mathrm{C} 8$ (4b) in vivo is consistent with the presence of OTR dimers or higher-order oligomers in native tissues, thus extending the finding of OTR oligomers previously reported in the rat mammary gland ${ }^{59}$ to the central nervous system. Remarkably, the only slight decrease in potency observed in vivo in mice and zebrafish as compared to in vitro studies on human receptors represent a proof of principle of the high value of these analogues for translational studies in neurodevelopmental and psychiatric disorders. As dOTK (2) binds with good affinity also to mouse V1a and V1b vasopressin receptors, ${ }^{60} \mathrm{dOTK}_{2}-$ C8 (4b) could in principle also be hitting V1a and/or V1b homodimers as well as OTR/V1a, OTR/V1b, or V1a/V1b heterodimers. However, because we have previously shown that the selectivity of dOTK (2) toward the OTR increases by a factor 100 when the amino group of its lysine in position 8 is no longer available, ${ }^{30}$ we believe that the selectivity profile of the bivalent $\mathrm{dOTK}_{2}-\mathrm{C} 8(\mathbf{4 b})$ analogue toward the OTR could be improved as well. In vivo experiments in vasopressin receptor null models and/or with selective antagonists should be performed to fully address this point.

In conclusion, this new bivalent ligand class shows great potential in paving the way for the development of advanced molecular tools and therapeutics targeting the OTR in important diseases such as autism and schizophrenia. The findings and methodology reported and developed here should also be highly applicable to other GPCR signaling systems.

\section{EXPERIMENTAL SECTION}

Peptide Synthesis. Peptidic monovalent ligands were synthesized on a CS Bio CS336X peptide synthesizer using Fmoc solid-phase peptide synthesis (SPPS). ${ }^{61}$ Following cleavage from resin, peptides were folded by air oxidation in $0.1 \mathrm{~mol}$ ammonium bicarbonate $(\mathrm{pH}$ 8.2) for $24 \mathrm{~h}$. Peptides were analyzed and purified by analytical RPHPLC (Phenomenex Jupiter C18, $4 \mu \mathrm{m}, 150 \mathrm{~mm} \times 4.6 \mathrm{~mm}$ ) using a linear gradient of $0-60 \% \mathrm{~B}$ (solvent $\mathrm{A}, \mathrm{H}_{2} \mathrm{O} / 0.05 \%$ TFA; solvent $\mathrm{B}$, $90 \% \mathrm{CH}_{3} \mathrm{CN} / 10 \% \mathrm{H}_{2} \mathrm{O} / 0.043 \% \mathrm{TFA}$ ) in $60 \mathrm{~min}$ at $1 \mathrm{~mL} / \mathrm{min}$ while monitoring $\mathrm{UV}$ absorbance at $214 \mathrm{~nm}$. MS analysis was carried out on an API 2000 from AB Sciex (Framingham, MA, USA). The purity of all compounds was $>95 \%$. The bivalent ligands were synthesized via an adapted method of Gera et al. ${ }^{62}$ that utilized a disuccinimidyl (DSS) spacer to conjugate two monomers to form the bivalent ligand. Briefly, two equivalents of dOTK and one equivalent of the DSS spacer were dissolved in anhydrous $N, N$-dimethylformamide (DMF), followed by the addition of three equivalents of $\mathrm{N}, \mathrm{N}$-diisopropylethylamine (DIEA) in anhydrous DMF to the solution. The reaction mixture was left for $6 \mathrm{~h}$ and monitored by analytical RP-HPLC and LCMS. For the compounds, where the DSS ester of the dicarboxylic acid was not commercially available (C6 and C14), the DSS esters were created in situ using $N$-hydroxysuccinimide (NHS) in the presence of $N, N^{\prime}$ diisopropylcarbodiimide (DIC) and DIEA, as described in ref 8 . Additional details on the synthesis can be found in Supporting Information, Experimental Section.

OTR transmembrane (TMH) peptides were designed and synthesized together with a portion of the highly polar HIV transactivator of transcription, HIV TAT (GRKKRRQRRR), added to the $\mathrm{C}$-terminus of TMH peptides to aid in plasma membrane insertion and correct orientation and to improve the peptide's solubility. ${ }^{50}$ Their sequences are shown in Figure $7 \mathrm{~A}$, and more details are reported in Supporting Information, Experimental Section.

Cell Culture and Transfection. Human embryonic kidney 293 (HEK293) cells were purchased from the American Type Culture Collection (Manassas, VA) and were cultured in Dulbecco's modified Eagle's medium (DMEM) (Sigma-Aldrich, St. Louis, MO, USA) supplemented with 5\% (v/v) FBS (Sigma-Aldrich), 100 units of penicillin (Sigma-Aldrich), $100 \mathrm{~g} / \mathrm{mL}$ streptomycin (Sigma-Aldrich), and $2 \mathrm{mM}$ L-glutamine (Sigma-Aldrich). The day before transfection, cells were seeded in $100 \mathrm{~mm}$ plates or $35 \mathrm{~mm}$ plates. Transient transfections were performed using linear polyethyleimine $25 \mathrm{kDa}$ (PEI MW 25,000, Polysciences, Inc., Warrington, PA, USA) as transfecting agent, at a ratio of 3 to $1 \mathrm{PEI} /$ plasmid DNA. Twenty-four hours after transfection, the supplemented DMEM was renewed, and the cells were cultured for a further $24 \mathrm{~h}$ before the experiments.

BRET Assays. In the Gq BRET activation assay, DNA encoding for Renilla Luciferase (Rluc8)-tagged $\mathrm{G} \alpha_{\mathrm{q}}$ (the BRET energy donor) (4 $\mu \mathrm{g}), \mathrm{GFP}^{10}-\mathrm{G} \gamma_{2}$ (BRET energy acceptor) $(5 \mu \mathrm{g}), \mathrm{G} \beta_{1}(5 \mu \mathrm{g}) \mathrm{G}$ proteins subunits, and OTR constructs $(7 \mu \mathrm{g})$ were used. In OTR dimerization experiments, a fixed amount of OTR-Rluc $(3 \mu \mathrm{g})$ and saturating amount of OTR-GFP ${ }^{2}(9 \mu \mathrm{g})$ were used. HEK293 cells were transfected as described i refs 33 and 34. Forty-eight hours following transfection, cells were washed twice with PBS, detached, and resuspended in PBS plus $0.1 \%(\mathrm{w} / \mathrm{v})$ glucose at room temperature. Protein concentration, was determined using a 
colorimetric protein assay (DC protein assay, Biorad, Milan, Italy). For TMH peptide treatment, transfected cells were incubated with $1 \mu \mathrm{M}$ TMH peptides for $2 \mathrm{~h}$ at room temperature before BRET assays. Cells were then distributed ( $80 \mu \mathrm{g}$ of proteins per well) in a 96-well microplate (Optiplate, PerkinElmer, Milan, Italy) and incubated in the presence of various ligand concentrations or vehicle (PBS) for $2 \mathrm{~min}$ prior to the addition of the $\mathrm{BRET}^{2}$ substrate, coelenterazine 400A, also called Deep Blue C (Biotium, Hayward, CA). Immediately after the addition of coelenterazine $400 \mathrm{~A}(5 \mu \mathrm{M})$, Rluc and $\mathrm{GFP}^{10} / \mathrm{GFP}^{2}$ emissions were recorded using a multidetector plate reader Infinite F500 (Tecan, Milan, Italy) that allows the sequential integration of light signals detected with two filter settings (Rluc filter, $370-450 \mathrm{~nm}$; and $\mathrm{GFP}^{10} / \mathrm{GFP}^{2}$ filter, $510-540 \mathrm{~nm}$ ). Data were collected and the $\mathrm{BRET}^{2}$ signal determined as the ratio of the light emitted by acceptors $\left(\mathrm{GFP}^{10} / \mathrm{GFP}^{2}\right)$ over donors (Rluc8). The "ligand promoted BRET" value was calculated by subtracting the BRET signal measured with ligand from the one obtained in the vehicle condition as in ref 34 . In BRET saturation experiments, constant amounts of wild type or mutant C47A or V43A/C47A OTR-Rluc plasmid $(0.5 \mu \mathrm{g})$ were cotransfected in HEK293 cells with increasing amounts of the corresponding OTR-GFP ${ }^{2}$ plasmids $(0-1.5 \mu \mathrm{g}$ in $35 \mathrm{~mm} /$ well). CD4-GFP ${ }^{2}$ was used as a negative control of dimerization. The expression level of each tagged receptor was determined by direct measurement of total fluorescence and luminescence in an aliquot of the transfected cells. Total fluorescence was measured using a TECAN Infinite F500 microplate reader with an excitation filter at $340 \pm 25$ $\mathrm{nm}$ and an emission filter at $535 \pm 25 \mathrm{~nm}$ for $\mathrm{GFP}^{2} / \mathrm{GFP}^{10}$. After fluorescence measurement, the same cell sample was incubated for 8 min with $5 \mu \mathrm{M}$ coelenterazine h (Biotium, Hayward, CA, USA), and the total luminescence was measured (from 370 to $450 \mathrm{~nm}$ ) using a TECAN Infinite F500 microplate reader. BRET signals were calculated immediately after the adjunction of coelenterazine $400 \mathrm{~A}(5 \mu \mathrm{M}$, Biotium) using the Rluc filter, $370-450 \mathrm{~nm}$, and $\mathrm{GFP}^{2}$ filter, $510-540$ $\mathrm{nm}$, and were calculated as the ratio of the emission of $\mathrm{GFP}^{2}$ over the emission of Rluc. BRET saturation data were analyzed using the Graph Pad Prism 5.0 software by nonlinear regression assuming a one-phase exponential association.

Ligand Binding Assays. Binding assays were performed at $30^{\circ} \mathrm{C}$ on membranes prepared from COS7 cells as previously described. ${ }^{38}$ $\left.{ }^{[125} \mathrm{I}\right] \mathrm{d}\left(\mathrm{CH}_{2}\right)_{5}\left[\mathrm{Tyr}(\mathrm{Me})^{2}, \mathrm{Thr}^{4}\right.$, and Tyr-NH $\left.{ }_{2}{ }^{9}\right]$ OVT ([ $\left.{ }^{125} \mathrm{I}\right]$-OVTA) were purchased from PerkinElmer (Waltham, MA, USA). Compound affinities were determined by means of competition experiments in which the unlabeled compound concentrations varied from $10^{-15}$ to $10^{-6} \mathrm{M}$, and the concentration of the radioligand [ $\left.{ }^{125} \mathrm{I}\right]$-OVTA was $10^{-11} \mathrm{M}$. Nonspecific binding was determined in the presence of unlabeled OT $\left(10^{-6} \mathrm{M}\right)$. All assays were performed in triplicate and repeated at least thrice.

Homology Modeling and Ligand Docking. Details are provided in the Supporting Information, Experimental Section. Briefly, the monomeric OTR active conformation was built mainly on the basis of the $\beta 2$-adrenergic crystal structure (PDB ID 3SN6). ${ }^{63}$ Homodimeric OTR constellations were designed by using the $\mathrm{K}$ opioid receptor (KOR) (PDB ID 4DJH) and chemokine receptor type 4 (CXCR4) (PDB ID 3ODU) crystal structures as templates for protomer arrangements and to simulate dimer interfaces TMH1TMH2-H8 and TMH5-TMH6-intracellular loop 2 (ICL2), respectively. Monomeric OTR/dOTK (2) complexes were superimposed with the protomers of KOR and CXCR4 dimers in an inactive conformation (the only dimer conformations available at present in the literature).

For binding of the bivalent ligands into the dimeric OTR, we assumed identical binding modes of dOTK (2) in the putative orthosteric binding sites of OTR protomers forming the dimer, which was comparable to the monovalent ligand in a monomeric OTR. Therefore, in a first step, monovalent dOTKs were constrained in their binding mode at both protomers of the two hypothesized main OTR dimer constellations (see above) and connected by spacers with different lengths. These complexes were optimized concerning the spacers' bond-length and conformation. Initial minimization was performed by constraining the backbone of the TMHs and the ligand- backbone atoms. As none of the bivalent spacer lengths were suitable to bridge the distance between the dOTK moieties in the OTR dimer with a TMH5-TMH6-ICL2 interface by maintenance of the two orthosteric ligand binding sites, further molecular dynamic simulations were conducted only to the dimeric models with the TMH1-TMH2helix 8 interface, followed by energy minimization to justify and energetically optimize the bivalent ligand orientation inside the OTR dimers.

Site-Directed Mutagenesis. Enzymes for molecular cloning were purchased from New England Biolabs (Ipswich, MA, USA) and Promega (Madison, WI, USA). Oligonucleotides were synthesized by Eurofins MWG Operon (Ebersberg, Germany). DNA sequencing was performed by Eurofins MWG Operon (Ebersberg, Germany). DNA purification kits were obtained from Promega. PCR amplification was performed using the GC-rich PCR system (Roche, Monza, Italy). For cloning purposes, E. coli DH5 $\alpha$ bacteria were used (Invitrogen, Life Technologies, NY, USA).

All mutations were introduced into the hOTR-pRK5 ${ }^{64}$ using standard PCR mutagenesis techniques. ${ }^{65}$ The oligonucleotidic primers (reported in the Supporting Information, Experimental Section) were designed on the basis of the sequence deposited at the NCBI (accession number NM 000196).

Sociability and Social Preference. $\mathrm{Oxtr}^{+/-}$mice $^{66}$ were obtained from L. Young (Emory University, Atlanta, GA, USA) and housed as reported in the Supporting Information, Experimental Section. Adult WT zebrafish were obtained by a local aquarium supply store (Aquarium Center, Milan, Italy). All of the experimental procedures followed the guidelines established by the Italian Council on Animal Care and were approved by Italian Government Decree No. 17/2013 for mice and 18/2013 for zebrafish. Every effort was made to minimize the number of animals used and their suffering.

For the sociability test in mice, a rectangular, three-chamber transparent polycarbonate box was employed, and the test was conducted as previously described; ${ }^{52}$ procedural details are reported in Supporting Information, Experimental Section.

Social preference in zebrafish was carried out in a large glass aquarium according to a previous study. ${ }^{53}$ Briefly, a WT zebrafish test fish was allowed to recognize two shoal stimuli, a Nacre mutant, and a WT counterpart, located in two opposite areas of the aquarium for up to $15 \mathrm{~min}$ (further details are described in Supporting Information, Experimental Section). Shoaling preference was quantified by recording the total time spent by the WT test fish in proximity to each stimulus shoal.

OT (1) and $\mathrm{dOTK}_{2}-\mathrm{C} 8(\mathbf{4 b})$ were dissolved in cerebrospinal fluid and administered intracerebroventricularly (i.c.v) to mice via an implanted cannula (Supporting Information, Experimental Section) in a total volume of $2 \mu \mathrm{L}$ /mouse with a dose ranging from 0.005 to 0.5 $\mathrm{ng} /$ mouse, $10 \mathrm{~min}$ prior to the sociability test. For zebrafish, isotocin (IT) (Bachem, Bubendorf, Switzerland) and $\mathrm{dOTK}_{2}-\mathrm{C} 8$ were dissolved in saline and administered intramuscularly (i.m.) (Supporting Information, Experimental Section) immediately prior the start of the test, with doses ranging between 0.002 and $1 \mathrm{ng} / \mathrm{kg}$. All solutions were freshly prepared daily from stocks stored at $-20{ }^{\circ} \mathrm{C}$.

Data Analysis. Data analysis, statistical significance, and curve fitting were calculated using Graph-Pad Prism software, version 5 (GraphPad Software, Inc., San Diego, CA). To determine the best fitting, monophasic vs biphasic models were compared for each data set. Data points are reported as the mean \pm SEM. Estimated parameter values $\left(\mathrm{EC}_{50}\right.$, Hill coefficient, $\left.E_{\max }, K_{\mathrm{i}}\right)$ represent the mean $\pm \mathrm{SE}$ of at least three independent experiments each performed at least in triplicate.

BRET data of $\mathrm{Gq}$ activation were analyzed with a nonlinear regression curve fitting procedure. Monophasic curves where analyzed using the four-parameter logistic model:

$$
\begin{aligned}
Y= & \text { bottom }+(\text { top }- \text { bottom }) /\left(1+10^{\wedge}\left(\left(\log E C_{50}-X\right)\right.\right. \\
& * \text { Hill slope }))
\end{aligned}
$$

where top and bottom represent the lower and upper plateaus, respectively. 
Biphasic curves were analyzed using a seven parameters model for nonmonotonic curves ${ }^{67}$ as modified in ref 68 :

$$
\begin{aligned}
\delta= & \text { bottom }+\frac{\text { plateau }_{1}-\text { bottom }}{1+10^{\wedge}\left(\log E C_{50 \_1}-X\right) * b_{1}} \\
& +\frac{E_{\max }-\text { plateau }_{1}}{1+10^{\wedge}\left(\log E C_{50 \_2}-X\right) * b_{2}}
\end{aligned}
$$

where $\delta=$ response; $X=\log$ concentration of the agonist; bottom = response when $X=0 ; \mathrm{EC}_{50-1}$ and $\mathrm{EC}_{50-2}=$ concentrations of the agonist that produce half of the response of the first and second component, respectively; $b_{1}$ and $b_{2}=$ slopes of the first and second component, respectively; Plateau ${ }_{1}=$ maximal response of the first component; $E_{\max }=$ response for an infinite concentration of $\mathrm{X}$, with constrained $b_{1}$ and $b_{2}$ equal to -1 . Data from radioligand binding were evaluated by one-site and two-site competitive binding curve-fitting procedures using GraphPad Prism version 5. Synthetic transmembrane peptide effects on dimerization were analyzed by means of one-way ANOVA followed by Dunnett's posthoc test comparing all columns to the control (NT) column. Mice and zebrafish behavioral data were analyzed by means of one-way ANOVA for multiple comparisons followed by Tukey's or Bonferroni's posthoc test. A statistical level of significance of $P<0.05$ was accepted.

\section{ASSOCIATED CONTENT}

\section{S Supporting Information}

The Supporting Information is available free of charge on the ACS Publications website at DOI: 10.1021/acs.jmedchem.6b00564.

Supporting figures, supporting experimental section, and supporting notes (PDF)

PDB coordinates for docking pose of 2 in the monomeric OTR (PDB)

$\mathrm{PDB}$ coordinates for docking of $\mathbf{4 b}$ in the dimeric OTR (PDB)

PDB coordinates for docking of $4 \mathbf{e}$ in the dimeric OTR (PDB) SMILES data (CSV)

\section{AUTHOR INFORMATION}

\section{Corresponding Author}

*CNR, Institute of Neuroscience, Via Vanvitelli 32, 20129 Milano, Italy. Phone: +39-02-50316958. Fax: +39-0250317132. E-mail: b.chini@in.cnr.it.

\section{Author Contributions}

M.B. performed radioligand binding, functional assays, BRET experiments, FACS analysis and fluorescence microscopy, generated mutant receptors, performed data analysis, and wrote the manuscript. G.K. conducted docking and homology modeling, suggested receptor mutations, and wrote the manuscript. M.Mu. synthesized dOTK, dOTK $2-\mathrm{C} 6, \mathrm{dOTK}_{2}-$ C8, dOTK $2-\mathrm{C} 10$, dOTK $2-\mathrm{C} 12$, and $\mathrm{dOTK}_{2}-\mathrm{C} 14$ and wrote the manuscript. S.S. synthesized dOTK, dOTK $2-C 8$, dOTK$\mathrm{C} 8$, and wrote the corresponding experimental section. L.B., L.A.H., and P.J.M. designed and synthesized the disrupting peptides and edited the manuscript. M.Ma. planned and supervised dOTK, dOTK ${ }_{2}-\mathrm{C} 8$, and dOTK-C8 chemical synthesis and wrote the corresponding experimental section. D.B. and M.S. conceived and performed animal behavior assays, performed data analysis, and wrote the corresponding experimental section. S.D. generated mutant receptors. G.E.R. performed data analysis. T.B. performed data analysis and wrote the manuscript. B.C. conceived and supervised the project, performed radioligand binding and functional assays, performed data analysis, and wrote the manuscript.

\section{Notes}

The authors declare no competing financial interest.

Authors will release the atomic coordinates of presented 3Dmodels and experimental data upon article publication. (1) Oxytocin; (2) dOTK; (3) dOTK-C8; (4a) dOTK 2 -C6; (4b) $\mathrm{dOTK}_{2}-\mathrm{C} 8$; (4c) dOTK $2-\mathrm{C10}$; (4d) $\mathrm{dOTK}_{2}-\mathrm{C} 12$; and (4e) $\mathrm{dOTK}_{2}-\mathrm{C} 14$.

\section{ACKNOWLEDGMENTS}

This work was supported by the Telethon Foundation (grant GGP12207), CNR Research Project on Aging and Regione Lombardia (Project MbMM-convenzione no18099/RCC) to B.C.; European Union Seventh Framework Program (Marie Curie grant 254897 and 2013-BP-B-00109), the Secretary of Universities and Research of the Economy and Knowledge Department of the Government of Catalonia and ARC DECRA (DE150100784) to M.Mu.; DFG (grant KL2334/2-2) and EKFS project 2014_A114 to G.K.; the National Institute of General Medical Sciences (grant GM-25280) to M.Ma.; and BBSRC DTP funding to P.J.M. and L.A.H. (MCCORMICK_U15DTP1). M.B. is the recipient of a Foundation Umberto Veronesi postdoctoral fellowship. We thank Dr. C. Galés, INSERM, France who provided the BRET biosensor cDNAs and Fondazione Monzino for gifting the LSM510 META confocal laser-scanning microscope (Zeiss, Jena, Germany).

\section{ABBREVIATIONS USED}

BRET, bioluminescence resonance energy transfer; cAMP, cyclic adenosine 3',5'-monophosphate; CXCR4, chemokine receptor type 4; CSF, cerebrospinal fluid; DOTA, 1,4,7,10 tetraazacyclododecane-1,4,7,10-tetraacetic acid; ECL, extracellular loop; ICL, intracellular loop; FACS, fluorescence activated cell sorting; $\mathrm{GFP}^{2}$ and $\mathrm{GFP}^{10}$, blue shift variants of the green fluorescent protein; GPCR, G-protein coupled receptors; Gx, G-protein subunit; i.c.v., intracerebroventricular; i.m., intramuscular; IT, isotocin; KOR, K-opioid receptor; L, length; OT, oxytocin; OTR, oxytocin receptor; OVTA, d $\left(\mathrm{CH}_{2}\right)_{5}\left[\mathrm{Tyr}(\mathrm{Me})^{2}\right.$, $\mathrm{Thr}^{4}$, Tyr- $\mathrm{NH}_{2}{ }^{9}$ ] ornithine vasotocin; Rluc, Renilla reniformis Luciferase; TAT, portion of the HIV transactivator of transcription; TMH, transmembrane helix; V, volume; WT, wild-type

\section{REFERENCES}

(1) Bouvier, M. Oligomerization of G-protein-coupled transmitter receptors. Nat. Rev. Neurosci. 2001, 2, 274-286.

(2) Pin, J. P.; Neubig, R.; Bouvier, M.; Devi, L.; Filizola, M.; Javitch, J. A.; Lohse, M. J.; Milligan, G.; Palczewski, K.; Parmentier, M.; Spedding, M. International Union of Basic and Clinical Pharmacology. LXVII. Recommendations for the recognition and nomenclature of $G$ protein-coupled receptor heteromultimers. Pharmacol. Rev. 2007, 59, $5-13$.

(3) Ferre, S.; Casado, V.; Devi, L. A.; Filizola, M.; Jockers, R.; Lohse, M. J.; Milligan, G.; Pin, J. P.; Guitart, X. G protein-coupled receptor oligomerization revisited: functional and pharmacological perspectives. Pharmacol. Rev. 2014, 66, 413-434.

(4) Hiller, C.; Kuhhorn, J.; Gmeiner, P. Class A G-protein-coupled receptor (GPCR) dimers and bivalent ligands. J. Med. Chem. 2013, 56, $6542-6559$.

(5) Shonberg, J.; Scammells, P. J.; Capuano, B. Design strategies for bivalent ligands targeting GPCRs. ChemMedChem 2011, 6, 963-974.

(6) Valant, C.; Robert Lane, J.; Sexton, P. M.; Christopoulos, A. The best of both worlds? Bitopic orthosteric/allosteric ligands of $G$ 
protein-coupled receptors. Annu. Rev. Pharmacol. Toxicol. 2012, 52, 153-178.

(7) Lane, J. R.; Sexton, P. M.; Christopoulos, A. Bridging the gap: bitopic ligands of G-protein-coupled receptors. Trends Pharmacol. Sci. 2013, 34, 59-66.

(8) Daniels, D. J.; Lenard, N. R.; Etienne, C. L.; Law, P. Y.; Roerig, S. C.; Portoghese, P. S. Opioid-induced tolerance and dependence in mice is modulated by the distance between pharmacophores in a bivalent ligand series. Proc. Natl. Acad. Sci. U. S. A. 2005, 102, 1920819213.

(9) Smeester, B. A.; Lunzer, M. M.; Akgun, E.; Beitz, A. J.; Portoghese, P. S. Targeting putative mu opioid/metabotropic glutamate receptor-5 heteromers produces potent antinociception in a chronic murine bone cancer model. Eur. J. Pharmacol. 2014, 743, $48-52$.

(10) Akgun, E.; Javed, M. I.; Lunzer, M. M.; Powers, M. D.; Sham, Y. Y.; Watanabe, Y.; Portoghese, P. S. Inhibition of Inflammatory and Neuropathic Pain by Targeting a Mu Opioid Receptor/Chemokine Receptor5 Heteromer (MOR-CCR5). J. Med. Chem. 2015, 58, 86478657.

(11) Decker, M.; Fulton, B. S.; Zhang, B.; Knapp, B. I.; Bidlack, J. M.; Neumeyer, J. L. Univalent and bivalent ligands of butorphan: characteristics of the linking chain determine the affinity and potency of such opioid ligands. J. Med. Chem. 2009, 52, 7389-7396.

(12) Soulier, J. L.; Russo, O.; Giner, M.; Rivail, L.; Berthouze, M.; Ongeri, S.; Maigret, B.; Fischmeister, R.; Lezoualc'h, F.; Sicsic, S.; Berque-Bestel, I. Design and synthesis of specific probes for human 5HT4 receptor dimerization studies. J. Med. Chem. 2005, 48, 62206228.

(13) Zhang, B.; Zhang, T.; Sromek, A. W.; Scrimale, T.; Bidlack, J. M.; Neumeyer, J. L. Synthesis and binding affinity of novel mono- and bivalent morphinan ligands for kappa, mu, and delta opioid receptors. Bioorg. Med. Chem. 2011, 19, 2808-2816.

(14) Nimczick, M.; Pemp, D.; Darras, F. H.; Chen, X.; Heilmann, J.; Decker, M. Synthesis and biological evaluation of bivalent cannabinoid receptor ligands based on $\mathrm{hCB}(2) \mathrm{R}$ selective benzimidazoles reveal unexpected intrinsic properties. Bioorg. Med. Chem. 2014, 22, 39383946.

(15) Russo, O.; Berthouze, M.; Giner, M.; Soulier, J. L.; Rivail, L.; Sicsic, S.; Lezoualc'h, F.; Jockers, R.; Berque-Bestel, I. Synthesis of specific bivalent probes that functionally interact with 5-HT(4) receptor dimers. J. Med. Chem. 2007, 50, 4482-4492.

(16) Birnkammer, T.; Spickenreither, A.; Brunskole, I.; Lopuch, M.; Kagermeier, N.; Bernhardt, G.; Dove, S.; Seifert, R.; Elz, S.; Buschauer, A. The bivalent ligand approach leads to highly potent and selective acylguanidine-type histamine $\mathrm{H}(2)$ receptor agonists. J. Med. Chem. 2012, 55, 1147-1160.

(17) Lensing, C. J.; Freeman, K. T.; Schnell, S. M.; Adank, D. N.; Speth, R. C.; Haskell-Luevano, C. An in Vitro and in Vivo Investigation of Bivalent Ligands That Display Preferential Binding and Functional Activity for Different Melanocortin Receptor Homodimers. J. Med. Chem. 2016, 59, 3112-3128.

(18) Cottet, M.; Albizu, L.; Perkovska, S.; Jean-Alphonse, F.; Rahmeh, R.; Orcel, H.; Mejean, C.; Granier, S.; Mendre, C.; Mouillac, B.; Durroux, T. Past, present and future of vasopressin and oxytocin receptor oligomers, prototypical GPCR models to study dimerization processes. Curr. Opin. Pharmacol. 2010, 10, 59-66.

(19) Terrillon, S.; Durroux, T.; Mouillac, B.; Breit, A.; Ayoub, M. A.; Taulan, M.; Jockers, R.; Barberis, C.; Bouvier, M. Oxytocin and Vasopressin V1a and V2 Receptors Form Constitutive Homo- and Heterodimers during Biosynthesis. Mol. Endocrinol. 2003, 17, 677691.

(20) Romero-Fernandez, W.; Borroto-Escuela, D. O.; Agnati, L. F.; Fuxe, K. Evidence for the existence of dopamine D2-oxytocin receptor heteromers in the ventral and dorsal striatum with facilitatory receptorreceptor interactions. Mol. Psychiatry 2013, 18, 849-850.

(21) Wrzal, P. K.; Devost, D.; Petrin, D.; Goupil, E.; Iorio-Morin, C.; Laporte, S. A.; Zingg, H. H.; Hebert, T. E. Allosteric interactions between the oxytocin receptor and the beta2-adrenergic receptor in the modulation of ERK1/2 activation are mediated by heterodimerization. Cell. Signalling 2012, 24, 342-350.

(22) Wrzal, P. K.; Goupil, E.; Laporte, S. A.; Hebert, T. E.; Zingg, H. $\mathrm{H}$. Functional interactions between the oxytocin receptor and the beta2-adrenergic receptor: implications for ERK1/2 activation in human myometrial cells. Cell. Signalling 2012, 24, 333-341.

(23) Lee, H. J.; Macbeth, A. H.; Pagani, J. H.; Young, W. S., 3rd. Oxytocin: the great facilitator of life. Prog. Neurobiol. 2009, 88, 127151

(24) Meyer-Lindenberg, A.; Domes, G.; Kirsch, P.; Heinrichs, M. Oxytocin and vasopressin in the human brain: social neuropeptides for translational medicine. Nat. Rev. Neurosci. 2011, 12, 524-538.

(25) Andari, E.; Duhamel, J. R.; Zalla, T.; Herbrecht, E.; Leboyer, M.; Sirigu, A. Promoting social behavior with oxytocin in high-functioning autism spectrum disorders. Proc. Natl. Acad. Sci. U. S. A. 2010, 107, 4389-4394.

(26) Preti, A.; Melis, M.; Siddi, S.; Vellante, M.; Doneddu, G.; Fadda, R. Oxytocin and autism: a systematic review of randomized controlled trials. J. Child Adolesc. Psychopharmacol. 2014, 24, 54-68.

(27) Feifel, D.; Macdonald, K.; Nguyen, A.; Cobb, P.; Warlan, H.; Galangue, B.; Minassian, A.; Becker, O.; Cooper, J.; Perry, W.; Lefebvre, M.; Gonzales, J.; Hadley, A. Adjunctive intranasal oxytocin reduces symptoms in schizophrenia patients. Biol. Psychiatry 2010, 68, 678-680.

(28) Young, L. J.; Barrett, C. E. Neuroscience. Can oxytocin treat autism? Science 2015, 347, 825-826.

(29) Manning, M.; Misicka, A.; Olma, A.; Bankowski, K.; Stoev, S.; Chini, B.; Durroux, T.; Mouillac, B.; Corbani, M.; Guillon, G. Oxytocin and vasopressin agonists and antagonists as research tools and potential therapeutics. J. Neuroendocrinol. 2012, 24, 609-628.

(30) Chini, B.; Chinol, M.; Cassoni, P.; Papi, S.; Reversi, A.; Areces, L.; Marrocco, T.; Paganelli, G.; Manning, M.; Bussolati, G. Improved radiotracing of oxytocin receptor-expressing tumours using the new [111In]-DOTA-Lys8-deamino-vasotocin analogue. Br. J. Cancer 2003, 89, 930-936.

(31) Salahpour, A.; Espinoza, S.; Masri, B.; Lam, V.; Barak, L. S.; Gainetdinov, R. R. BRET biosensors to study GPCR biology, pharmacology, and signal transduction. Front. Endocrinol. (Lausanne, Switz.) 2012, 3, 105.

(32) Gales, C.; Rebois, R. V.; Hogue, M.; Trieu, P.; Breit, A.; Hebert, T. E.; Bouvier, M. Real-time monitoring of receptor and G-protein interactions in living cells. Nat. Methods 2005, 2, 177-184.

(33) Sauliere, A.; Bellot, M.; Paris, H.; Denis, C.; Finana, F.; Hansen, J. T.; Altie, M. F.; Seguelas, M. H.; Pathak, A.; Hansen, J. L.; Senard, J. M.; Gales, C. Deciphering biased-agonism complexity reveals a new active AT1 receptor entity. Nat. Chem. Biol. 2012, 8, 622-630.

(34) Busnelli, M.; Sauliere, A.; Manning, M.; Bouvier, M.; Gales, C.; Chini, B. Functional selective oxytocin-derived agonists discriminate between individual G protein family subtypes. J. Biol. Chem. 2012, 287, 3617-3629.

(35) Jonas, K. C.; Fanelli, F.; Huhtaniemi, I. T.; Hanyaloglu, A. C. Single molecule analysis of functionally asymmetric $\mathrm{G}$ protein-coupled receptor (GPCR) oligomers reveals diverse spatial and structural assemblies. J. Biol. Chem. 2015, 290, 3875-3892.

(36) Scarselli, M.; Annibale, P.; McCormick, P. J.; Kolachalam, S.; Aringhieri, S.; Radenovic, A.; Corsini, G. U.; Maggio, R. Revealing GPCR oligomerization at the single-molecule level through a nanoscopic lens: methods, dynamics and biological function. FEBS $J$. 2016, 283, 1197-1217.

(37) Albizu, L.; Balestre, M. N.; Breton, C.; Pin, J. P.; Manning, M.; Mouillac, B.; Barberis, C.; Durroux, T. Probing the existence of G protein-coupled receptor dimers by positive and negative liganddependent cooperative binding. Mol. Pharmacol. 2006, 70, 17831791.

(38) Chini, B.; Mouillac, B.; Ala, Y.; Balestre, M. N.; TrumppKallmeyer, S.; Hoflack, J.; Elands, J.; Hibert, M.; Manning, M.; Jard, S.; Barberis, C. Tyr115 is the key residue for determining agonist selectivity in the V1a vasopressin receptor. EMBO J. 1995, 14, 21762182. 
(39) Park, J. H.; Scheerer, P.; Hofmann, K. P.; Choe, H. W.; Ernst, O. P. Crystal structure of the ligand-free G-protein-coupled receptor opsin. Nature 2008, 454, 183-187.

(40) Scheerer, P.; Park, J. H.; Hildebrand, P. W.; Kim, Y. J.; Krauss, N.; Choe, H. W.; Hofmann, K. P.; Ernst, O. P. Crystal structure of opsin in its G-protein-interacting conformation. Nature 2008, 455, 497-502.

(41) Salom, D.; Lodowski, D. T.; Stenkamp, R. E.; Le Trong, I.; Golczak, M.; Jastrzebska, B.; Harris, T.; Ballesteros, J. A.; Palczewski, $\mathrm{K}$. Crystal structure of a photoactivated deprotonated intermediate of rhodopsin. Proc. Natl. Acad. Sci. U. S. A. 2006, 103, 16123-16128.

(42) Wu, H.; Wacker, D.; Mileni, M.; Katritch, V.; Han, G. W.; Vardy, E.; Liu, W.; Thompson, A. A.; Huang, X. P.; Carroll, F. I.; Mascarella, S. W.; Westkaemper, R. B.; Mosier, P. D.; Roth, B. L.; Cherezov, V.; Stevens, R. C. Structure of the human kappa-opioid receptor in complex with JDTic. Nature 2012, 485, 327-332.

(43) Wu, B.; Chien, E. Y.; Mol, C. D.; Fenalti, G.; Liu, W.; Katritch, V.; Abagyan, R.; Brooun, A.; Wells, P.; Bi, F. C.; Hamel, D. J.; Kuhn, P.; Handel, T. M.; Cherezov, V.; Stevens, R. C. Structures of the CXCR4 chemokine GPCR with small-molecule and cyclic peptide antagonists. Science 2010, 330, 1066-1071.

(44) Bonaventura, J.; Navarro, G.; Casado-Anguera, V.; Azdad, K.; Rea, W.; Moreno, E.; Brugarolas, M.; Mallol, J.; Canela, E. I.; Lluis, C.; Cortes, A.; Volkow, N. D.; Schiffmann, S. N.; Ferre, S.; Casado, V. Allosteric interactions between agonists and antagonists within the adenosine A2A receptor-dopamine D2 receptor heterotetramer. Proc. Natl. Acad. Sci. U. S. A. 2015, 112, E3609-3618.

(45) Guitart, X.; Navarro, G.; Moreno, E.; Yano, H.; Cai, N. S.; Sanchez-Soto, M.; Kumar-Barodia, S.; Naidu, Y. T.; Mallol, J.; Cortes, A.; Lluis, C.; Canela, E. I.; Casado, V.; McCormick, P. J.; Ferre, S. Functional selectivity of allosteric interactions within $G$ proteincoupled receptor oligomers: the dopamine D1-D3 receptor heterotetramer. Mol. Pharmacol. 2014, 86, 417-429.

(46) Vinals, X.; Moreno, E.; Lanfumey, L.; Cordomi, A.; Pastor, A.; de La Torre, R.; Gasperini, P.; Navarro, G.; Howell, L. A.; Pardo, L.; Lluis, C.; Canela, E. I.; McCormick, P. J.; Maldonado, R.; Robledo, P. Cognitive Impairment Induced by Delta9-tetrahydrocannabinol Occurs through Heteromers between Cannabinoid CB1 and Serotonin 5-HT2A Receptors. PLoS Biol. 2015, 13, e1002194.

(47) Lee, L. T.; Ng, S. Y.; Chu, J. Y.; Sekar, R.; Harikumar, K. G.; Miller, L. J.; Chow, B. K. Transmembrane peptides as unique tools to demonstrate the in vivo action of a cross-class GPCR heterocomplex. FASEB J. 2014, 28, 2632-2644.

(48) Navarro, G.; Quiroz, C.; Moreno-Delgado, D.; Sierakowiak, A.; McDowell, K.; Moreno, E.; Rea, W.; Cai, N. S.; Aguinaga, D.; Howell, L. A.; Hausch, F.; Cortes, A.; Mallol, J.; Casado, V.; Lluis, C.; Canela, E. I.; Ferre, S.; McCormick, P. J. Orexin-corticotropin-releasing factor receptor heteromers in the ventral tegmental area as targets for cocaine. J. Neurosci. 2015, 35, 6639-6653.

(49) Jastrzebska, B.; Chen, Y.; Orban, T.; Jin, H.; Hofmann, L.; Palczewski, K. Disruption of Rhodopsin Dimerization with Synthetic Peptides Targeting an Interaction Interface. J. Biol. Chem. 2015, 290, 25728-25744.

(50) Deshayes, S.; Morris, M. C.; Divita, G.; Heitz, F. Cellpenetrating peptides: tools for intracellular delivery of therapeutics. Cell. Mol. Life Sci. 2005, 62, 1839-1849.

(51) Yatawara, C. J.; Einfeld, S. L.; Hickie, I. B.; Davenport, T. A.; Guastella, A. J. The effect of oxytocin nasal spray on social interaction deficits observed in young children with autism: a randomized clinical crossover trial. Mol. Psychiatry 2015, DOI: 10.1038/mp.2015.162.

(52) Sala, M.; Braida, D.; Donzelli, A.; Martucci, R; Busnelli, M.; Bulgheroni, E.; Rubino, T.; Parolaro, D.; Nishimori, K.; Chini, B. Mice heterozygous for the oxytocin receptor gene $(\operatorname{Oxtr}( \pm))$ show impaired social behaviour but not increased aggression or cognitive inflexibility: evidence of a selective haploinsufficiency gene effect. J. Neuroendocrinol. 2013, 25, 107-118.

(53) Braida, D.; Donzelli, A.; Martucci, R.; Capurro, V.; Busnelli, M.; Chini, B.; Sala, M. Neurohypophyseal hormones manipulation modulate social and anxiety-related behavior in zebrafish. Psychopharmacology (Berl) 2012, 220, 319-330.

(54) Kramer, R. H.; Karpen, J. W. Spanning binding sites on allosteric proteins with polymer-linked ligand dimers. Nature 1998, 395, 710-713.

(55) Numata, J.; Juneja, A.; Diestler, D. J.; Knapp, E. W. Influence of spacer-receptor interactions on the stability of bivalent ligand-receptor complexes. J. Phys. Chem. B 2012, 116, 2595-2604.

(56) Johnston, J. M.; Wang, H.; Provasi, D.; Filizola, M. Assessing the relative stability of dimer interfaces in $\mathrm{g}$ protein-coupled receptors. PLoS Comput. Biol. 2012, 8, e1002649.

(57) Kasai, R. S.; Suzuki, K. G.; Prossnitz, E. R.; Koyama-Honda, I.; Nakada, C.; Fujiwara, T. K.; Kusumi, A. Full characterization of GPCR monomer-dimer dynamic equilibrium by single molecule imaging. $J$. Cell Biol. 2011, 192, 463-480.

(58) Calebiro, D.; Rieken, F.; Wagner, J.; Sungkaworn, T.; Zabel, U.; Borzi, A.; Cocucci, E.; Zurn, A.; Lohse, M. J. Single-molecule analysis of fluorescently labeled G-protein-coupled receptors reveals complexes with distinct dynamics and organization. Proc. Natl. Acad. Sci. U. S. A. 2013, 110, 743-748.

(59) Albizu, L.; Cottet, M.; Kralikova, M.; Stoev, S.; Seyer, R.; Brabet, I.; Roux, T.; Bazin, H.; Bourrier, E.; Lamarque, L.; Breton, C.; Rives, M. L.; Newman, A.; Javitch, J.; Trinquet, E.; Manning, M.; Pin, J. P.; Mouillac, B.; Durroux, T. Time-resolved FRET between GPCR ligands reveals oligomers in native tissues. Nat. Chem. Biol. 2010, 6, $587-594$.

(60) Busnelli, M.; Bulgheroni, E.; Manning, M.; Kleinau, G.; Chini, B. Selective and potent agonists and antagonists for investigating the role of mouse oxytocin receptors. J. Pharmacol. Exp. Ther. 2013, 346, $318-$ 327.

(61) Koehbach, J.; O’Brien, M.; Muttenthaler, M.; Miazzo, M.; Akcan, M.; Elliott, A. G.; Daly, N. L.; Harvey, P. J.; Arrowsmith, S.; Gunasekera, S.; Smith, T. J.; Wray, S.; Goransson, U.; Dawson, P. E.; Craik, D. J.; Freissmuth, M.; Gruber, C. W. Oxytocic plant cyclotides as templates for peptide $\mathrm{G}$ protein-coupled receptor ligand design. Proc. Natl. Acad. Sci. U. S. A. 2013, 110, 21183-21188.

(62) Gera, L.; Stewart, J. M.; Whalley, E.; Burkard, M.; Zuzack, J. S. A new class of potent bradykinin antagonist dimers. Immunopharmacology 1996, 33, 178-182.

(63) Rasmussen, S. G.; DeVree, B. T.; Zou, Y.; Kruse, A. C.; Chung, K. Y.; Kobilka, T. S.; Thian, F. S.; Chae, P. S.; Pardon, E.; Calinski, D.; Mathiesen, J. M.; Shah, S. T.; Lyons, J. A.; Caffrey, M.; Gellman, S. H.; Steyaert, J.; Skiniotis, G.; Weis, W. I.; Sunahara, R. K.; Kobilka, B. K. Crystal structure of the beta2 adrenergic receptor-Gs protein complex. Nature 2011, 477, 549-555.

(64) Fanelli, F.; Barbier, P.; Zanchetta, D.; de Benedetti, P. G.; Chini, B. Activation mechanism of human oxytocin receptor: a combined study of experimental and computer-simulated mutagenesis. Mol. Pharmacol. 1999, 56, 214-225.

(65) Higuchi, R.; Krummel, B.; Saiki, R. K. A general method of in vitro preparation and specific mutagenesis of DNA fragments: study of protein and DNA interactions. Nucleic Acids Res. 1988, 16, 73517367.

(66) Takayanagi, Y.; Yoshida, M.; Bielsky, I. F.; Ross, H. E.; Kawamata, M.; Onaka, T.; Yanagisawa, T.; Kimura, T.; Matzuk, M. M.; Young, L. J.; Nishimori, K. Pervasive social deficits, but normal parturition, in oxytocin receptor-deficient mice. Proc. Natl. Acad. Sci. U. S. A. 2005, 102, 16096-16101.

(67) Rovati, G. E.; Nicosia, S. Lower efficacy: interaction with an inhibitory receptor or partial agonism? Trends Pharmacol. Sci. 1994, 15, $140-144$.

(68) Ambrosio, M.; Fanelli, F.; Brocchetti, S.; Raimondi, F.; Mauri, M.; Rovati, G. E.; Capra, V. Superactive mutants of thromboxane prostanoid receptor: functional and computational analysis of an active form alternative to constitutively active mutants. Cell. Mol. Life Sci. 2010, 67, 2979-2989. 